Argonne

\title{
Summary of Operations and Performance of the Utica Aquifer and North Lake Basin Wetlands Restoration Project in December 2008-November 2009
}

Environmental Science Division 
About Argonne National Laboratory

Argonne is a U.S. Department of Energy laboratory managed by UChicago Argonne, LLC under contract DE-AC02-06CH11357. The Laboratory's main facility is outside Chicago, at 9700 South Cass Avenue, Argonne, Illinois 60439. For information about Argonne and its pioneering science and technology programs, see www.anl.gov.

\section{Availability of This Report}

This report is available, at no cost, at http://www.osti.gov/bridge. It is also available on paper to the U.S. Department of Energy and its contractors, for a processing fee, from:

U.S. Department of Energy

Office of Scientific and Technical Information

P.O. Box 62

Oak Ridge, TN 37831-0062

phone (865) 576-8401

fax (865) 576-5728

reports@adonis.osti.gov

\section{Disclaimer}

This report was prepared as an account of work sponsored by an agency of the United States Government. Reference herein to any specific commercial product, process, or service by trade name, trademark, manufacturer, or otherwise, does not necessarily constitute or imply its endorsement, recommendation, or favoring by the United States Government or any agency thereof. The views and opinions of document authors expressed herein do not necessarily state or reflect those of the United States Government or any agency thereof, Argonne National Laboratory, or UChicago Argonne, LLC. 


\section{Summary of Operations and Performance of the Utica Aquifer and North Lake Basin Wetlands Restoration Project in December 2008-November 2009}

by

Applied Geosciences and Environmental Management Section Environmental Science Division, Argonne National Laboratory

February 2010 


\section{Contents}

Notation.

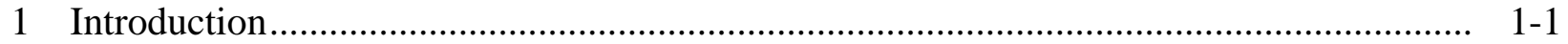

2 Overview of the Aquifer Restoration Facilities at Utica ................................................... 2-1

2.1 Wells GWEX1-GWEX3 and the Spray Irrigation Treatment Units........................ 2-1

2.2 Well GWEX4 and the Conventional Air Stripper .............................................. 2-1

2.3 Monitoring Well Network................................................................................... 2-2

3 Overview of System Operations …………………….................................................. 3-1

3.1 Operation of Wells GWEX1-GWEX3 and the Spray Irrigation Treatment Units .... 3-1

3.2 Operation of Well GWEX4 and the Conventional Air Stripper ............................. 3-2

4 Groundwater Production Results .......................................................................... 4-1

4.1 Production by Wells GWEX1-GWEX3 …...................................................... 4-1

4.2 Production by Well GWEX4 …......................................................................... $4-2$

5 Groundwater Treatment Results .................................................................................... 5-1

5.1 Results for Wells GWEX1-GWEX3, with Treatment by Spray Irrigation .............. 5-2

5.2 Results for Well GWEX4, with Treatment by Air Stripping.................................... 5-3

5.3 Estimated Removal of Carbon Tetrachloride from the Utica Aquifer...................... 5-4

5.4 Sampling of Monitoring Wells and Apparent Carbon Tetrachloride Concentration Trends in the Utica Groundwater.............................................................................

5.5 Evaluation of Groundwater Inorganic Geochemistry ........................................ $5-5$

6 Operation, Maintenance, and System Modifications ............................................................. 6-1

6.1 Wells GWEX1-GWEX3 and the Spray Irrigation Treatment Units....................... 6-1

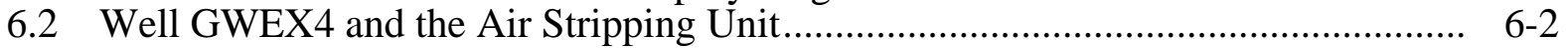

6.3 Operating and Maintenance Costs ................................................................... $6-3$

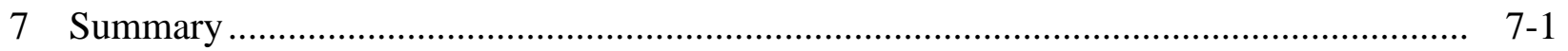

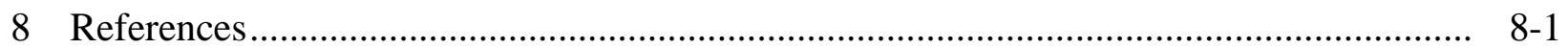




\section{Figures}

2.1 Locations of the restoration facilities, contaminant plume, and permanent monitoring wells at Utica.

2.2 Spray irrigation unit in operation at Utica

3.1a Servicing of extraction well GWEX4, October 2009, by personnel of Webster Drilling, Inc.

3.1b Corrosion and perforation identified in the steel riser pipe of well GWEX4, October 2009.

3.1c Corrosion and perforation identified in the downhole pump casing of well GWEX4, October 2009.

5.1 Carbon tetrachloride concentrations at monitoring wells MW1-MW4, September 2005 to November 2009

5.2 Carbon tetrachloride concentrations at extraction well GWEX1, November 2004 to November 2009.

5.3 Carbon tetrachloride concentrations at extraction well GWEX2, November 2004 to November 2009.

5.4 Carbon tetrachloride concentrations at extraction well GWEX3, November 2004 to November 2009.

5.5 Carbon tetrachloride concentrations at extraction well GWEX4, November 2004 to November 2009.

6.1 Locations proposed by the Nebraska Game and Parks Commission for the surveying of topographic elevations and the installation of permanent water level gauging staffs at the North Lake Basin Wildlife Management Area

6.2 Installation of H-piling in the north wetlands subbasin to support a permanent water level gauging staff, March 2009

6.3 Graduated water level gauging staffs to be installed in the wetlands subbasins 


\section{Tables}

2.1 Summary of construction details for GWEX wells at Utica....................................... 2-2

4.1 GWEX operation and groundwater production data in December 2008November 2009.

4.2 Comparison of actual well production rates and target rates

5.1 Analytical results for carbon tetrachloride in untreated groundwater samples and treated effluent samples in December 2008-November 2009.

5.2 Values for $\mathrm{pH}$ in untreated groundwater samples and treated effluent samples in December 2008-November 2009

5.3 Estimation of carbon tetrachloride removed from the Utica aquifer in December 2008-November 2009

5.4 Well construction data and analytical results for carbon tetrachloride in groundwater samples from the permanant monitoring wells.

5.5 Comparison of inorganic geochemical results for untreated groundwater samples and treated effluent samples.

6.1 Summary of operating and maintenance costs for the Utica restoration project ...........

7.1 Summary of performance of the groundwater restoration systems at Utica.

7.2 Results of the groundwater extraction and treatment efforts at Utica, November 2004 to November 2009. 
Utica Annual Review, December 2008-November 2009

Version 00, 02/22/10

\section{Notation}

$\begin{array}{ll}\text { BGL } & \text { below ground level } \\ \text { CCC } & \text { Commodity Credit Corporation } \\ \mathrm{ft} & \text { foot (feet) } \\ \text { gal } & \text { gallon(s) } \\ \text { gpm } & \text { gallon(s) per minute } \\ \text { GWEX } & \text { groundwater extraction } \\ \text { hr } & \text { hour(s) } \\ \text { in. } & \text { inch(es) } \\ \text { kg } & \text { kilogram(s) } \\ \text { L } & \text { liter(s) } \\ \mu \text { g/L } & \text { microgram(s) per liter } \\ \text { mg/L } & \text { milligram(s) per liter } \\ \text { MW } & \text { monitoring well } \\ \text { NDEQ } & \text { Nebraska Department of Environmental Quality } \\ \text { NGPC } & \text { Nebraska Game and Parks Commission } \\ \text { NPDES } & \text { National Pollutant Discharge Elimination System } \\ \text { USDA } & \text { U.S. Department of Agriculture } \\ \text { VOC } & \text { volatile organic compound } \\ \text { yr } & \text { year(s) }\end{array}$




\section{Summary of Operations and Performance of the Utica Aquifer and North Lake Basin Wetlands Restoration Project in December 2008-November 2009}

\section{Introduction}

This document summarizes the performance of the groundwater restoration systems installed by the Commodity Credit Corporation of the U.S. Department of Agriculture (CCC/USDA) at the former CCC/USDA grain storage facility in Utica, Nebraska, during the fifth year of system operation, from December 1, 2008, until November 30, 2009. Performance in earlier years was reported previously (Argonne 2005, 2006, 2008, 2009a).

In the project at Utica, the CCC/USDA is cooperating with multiple state and federal agencies to remove carbon tetrachloride contamination from a shallow aquifer underlying the town and to provide supplemental treated groundwater for use in the restoration of a nearby wetlands area. Argonne National Laboratory has assisted the CCC/USDA by providing technical oversight for the aquifer restoration effort and facilities during this review period.

This document presents overviews of the aquifer restoration facilities (Section 2) and system operations (Section 3), then describes groundwater production results (Section 4), groundwater treatment results (Section 5), and associated groundwater monitoring, system modifications, and costs during the review period (Section 6). Section 7 summarizes the present year of operation. 


\section{Overview of the Aquifer Restoration Facilities at Utica}

The principal components of the groundwater restoration systems at Utica are shown in Figure 2.1. The facilities consist of two main operating units, as described below. The facilities include four groundwater extraction (GWEX) wells. Table 2.1 summarizes construction details for these wells.

\subsection{Wells GWEX1-GWEX3 and the Spray Irrigation Treatment Units}

Extraction wells GWEX1-GWEX3, located in the northern portion of the town, are used to extract contaminated groundwater from the upgradient portion of the contaminant plume. These wells are linked by a distribution system that selectively carries untreated groundwater to either of two discharge points in the northern and southern subbasins of the North Lake Basin Wildlife Management Area (Figure 2.1). At each discharge point, the water is treated to remove carbon tetrachloride by using a custom spray irrigation treatment unit (Figure 2.2). The three extraction wells are operated simultaneously to maintain a critical operating pressure at each treatment unit.

Wells GWEX1-GWEX3 are operated intermittently during the year, subject to local weather conditions and in consultation with the Nebraska Game and Parks Commission (NGPC). The NGPC owns most of the property occupied by the wetlands and has administrative and technical responsibility for management of the wildlife area.

\subsection{Well GWEX4 and the Conventional Air Stripper}

Extraction well GWEX4 is located near the downgradient toe of the carbon tetrachloride plume and is operated continuously as a containment well. Groundwater produced from GWEX4 is treated by using a conventional (shallow-tray) air stripping technique, and the effluent is discharged to the surface for reinfiltration into the shallow Utica aquifer. 


\subsection{Monitoring Well Network}

A network of seven permanent monitoring points has been established at Utica (Figure 2.1). Wells SB48, SB71, and SB72 were constructed during the early phases of the investigations at Utica. These wells were intended primarily for the measurement of groundwater levels; they do not penetrate the more contaminated zones of the groundwater column identified in detailed vertical-profile sampling (Argonne 2000). To improve monitoring coverage, additional wells MW1-MW4 were installed at strategic locations along the plume migration pathway in August 2005.

TABLE 2.1 Summary of construction details for GWEX wells at Utica.

\begin{tabular}{ccccc}
\hline & \multicolumn{3}{c}{ Depth (ft BGL) } & \\
\cline { 2 - 4 } Well & Depth & $\begin{array}{c}\text { Screen } \\
\text { Interval }\end{array}$ & $\begin{array}{c}\text { Gravel } \\
\text { Pack } \\
\text { Interval }\end{array}$ & $\begin{array}{c}\text { Casing } \\
\text { Diameter } \\
\text { (in.) }\end{array}$ \\
\hline GWEX1 & 132 & $106-126$ & $97-132$ & 8 \\
GWEX2 & 148 & $110-145$ & $106-148$ & 8 \\
GWEX3 & 146 & $105-140$ & $101-146$ & 8 \\
GWEX4 & 150 & $115-145$ & $110-150$ & 6 \\
\hline
\end{tabular}




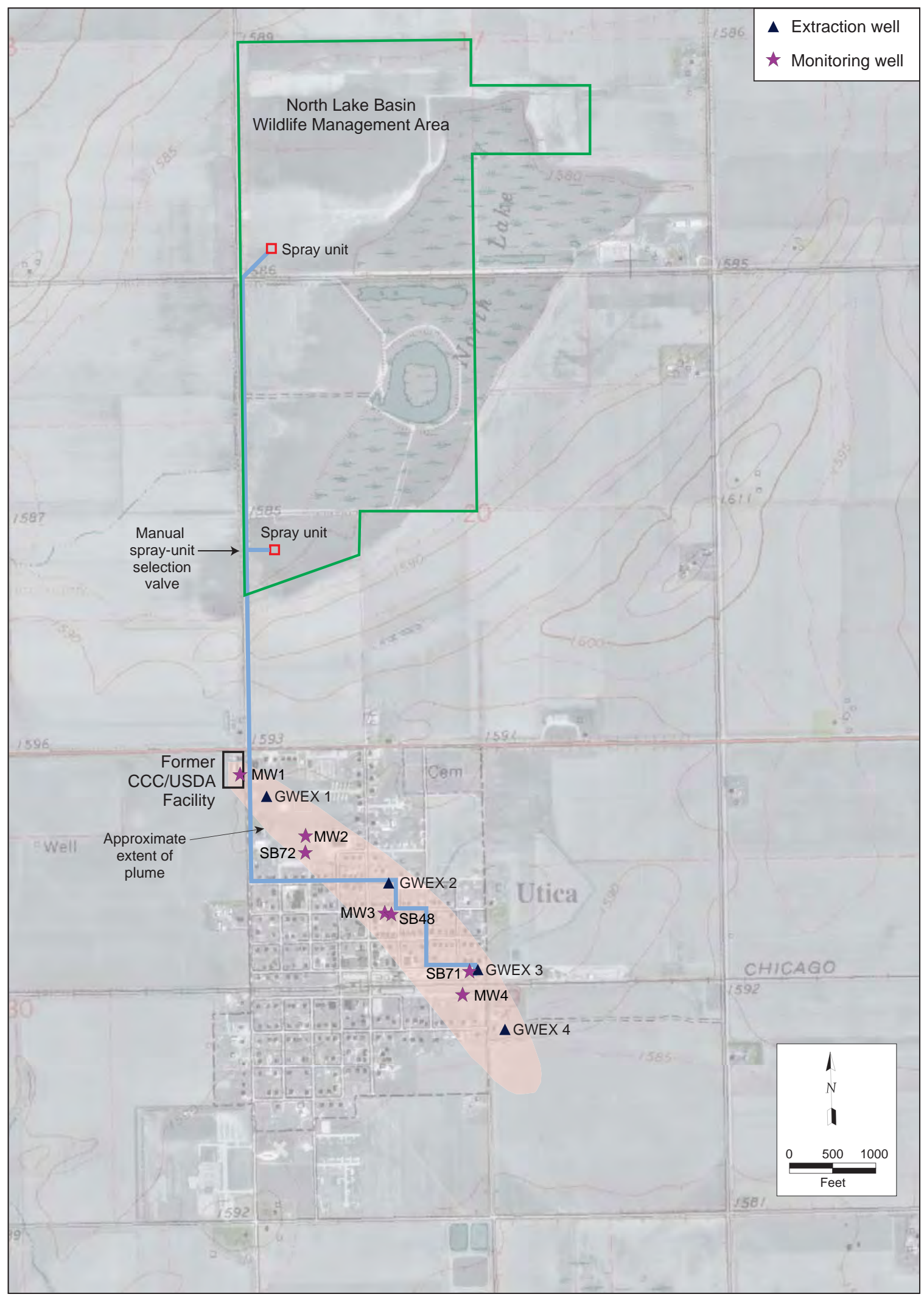

FIGURE 2.1 Locations of the restoration facilities, contaminant plume, and permanent monitoring wells at Utica. 


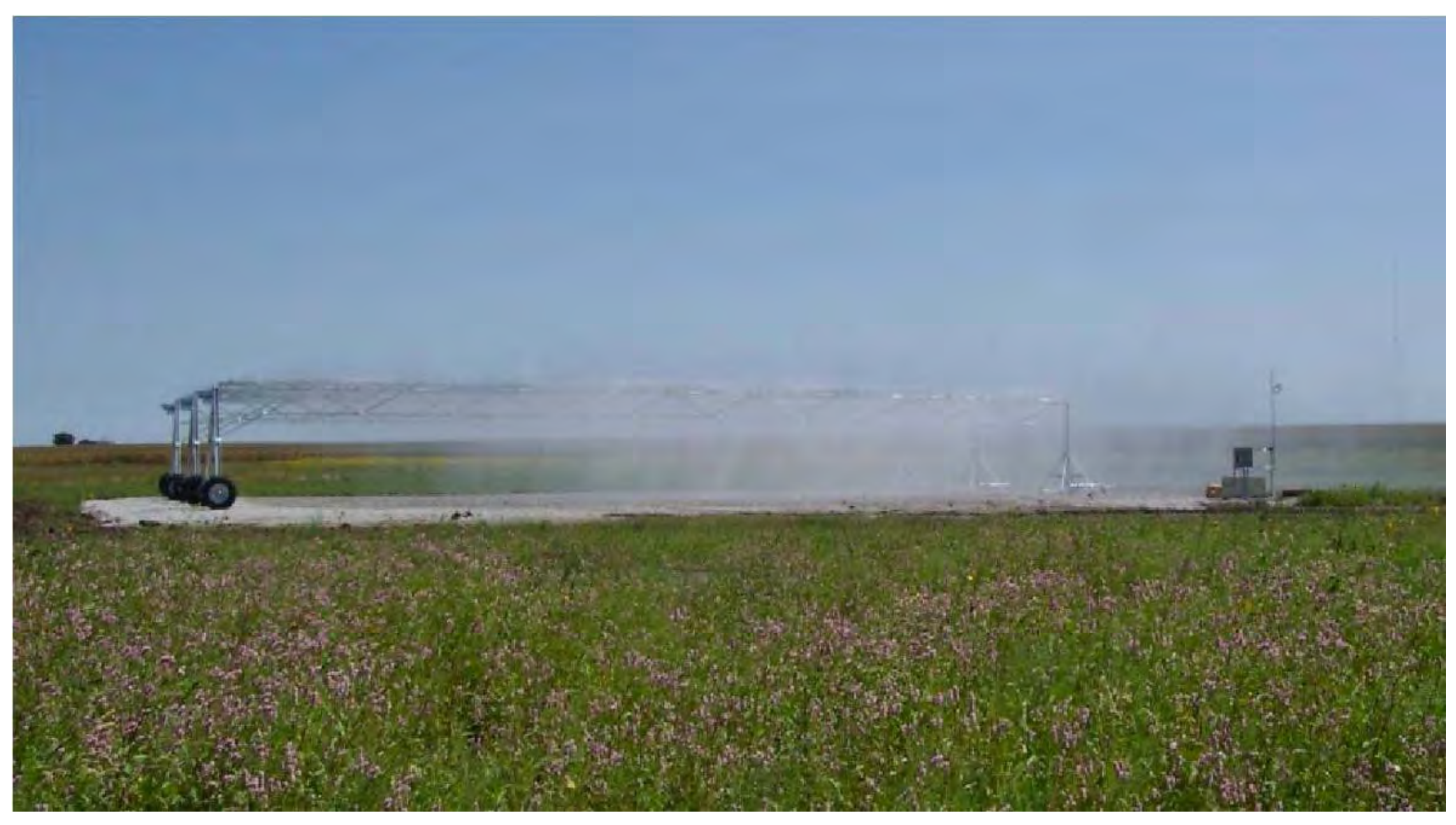




\section{Overview of System Operations}

The groundwater restoration program at Utica is conducted in accordance with a National Pollutant Discharge Elimination System (NPDES) permit (No. NE0137456) originally granted by the State of Nebraska, Department of Environmental Quality (NDEQ) for the 5-yr period October 1, 2004, to September 30, 2009. In accord with NPDES requirements, the CCC/USDA submitted an application for renewal of the permit to the NDEQ during the current review period. On September 28, 2009, the CCC/USDA received notice from the NDEQ that the term of the existing NPDES permit has been extended indefinitely, pending review of the renewal application.

\subsection{Operation of Wells GWEX1-GWEX3 and the Spray Irrigation Treatment Units}

Wells GWEX1-GWEX3 and the spray irrigation treatment units operated intermittently, under automated control, during only 6 of the 12 months in the current review period (December 2008-November 2009). The daily operation of the spray treatment units during this period was governed by both weather conditions and the available storage capacity of the wetlands basin to accept treated groundwater.

In response to concerns expressed by local property owners regarding flooding of the adjacent private croplands, operation of the spray irrigation units was discontinued in August 2008 for the remainder of the previous (December 2007-November 2008) review period, at the request of the NGPC (Argonne 2009a). During much of winter 2008-2009 and spring 2009, persistent high surface water levels in the wetlands precluded the addition of treated groundwater. As surface water levels receded during the summer and fall, treated groundwater from the spray irrigation systems was selectively routed to the north subbasin in June-August 2009 and to the south subbasin in September-November 2009.

Intermittent but recurring electrical problems experienced throughout much of the current review period affected the sprayer control panels and spray discharge pressure sensors at both the north and south spray pads. The problems resulted, in part, from major lightning storms in early August. The panels at both spray pads were serviced by the manufacturer (Reinke Manufacturing, Inc.), and the pressure sensors and connecting wiring were replaced in September-October 2009. The electrical surge protection devices serving the control panels were 
also upgraded at this time. The spray treatment units have functioned normally since these repairs.

\subsection{Operation of Well GWEX4 and the Conventional Air Stripper}

Well GWEX4 and the associated air stripper were operated during all 12 months of the review period.

Well GWEX4 and the air stripper ran continuously from December 2008 until early July 2009. On July 9, 2009, the units were shut down at the request of the Seward County Department of Roads, to facilitate maintenance of the open ditch into which the GWEX4 discharge is routed. This ditch forms part of the Utica storm drainage system at the southwest edge of the town (Figure 2.1). Operation of the well and air stripper was resumed on August 4, 2009. However, a reduction in the flow rate from the well was observed - from 62-65 gpm (gallons per minute) prior to the shutdown to approximately $51 \mathrm{gpm}$ after the restart. The flow from the well continued to decline (to approximately $25 \mathrm{gpm}$ by the end of September), and GWEX4 was again shut down in early October for inspection. The leakage discovered within the well casing was due to corrosion and perforation of both the downhole pump and the connecting riser pipe (Figures 3.1a-c). The pump, the connecting electrical wiring, and the riser pipe were replaced, and the well was returned to service on October 23, 2009. Well GWEX4 and the air stripper then operated normally for the remainder of the review period. 


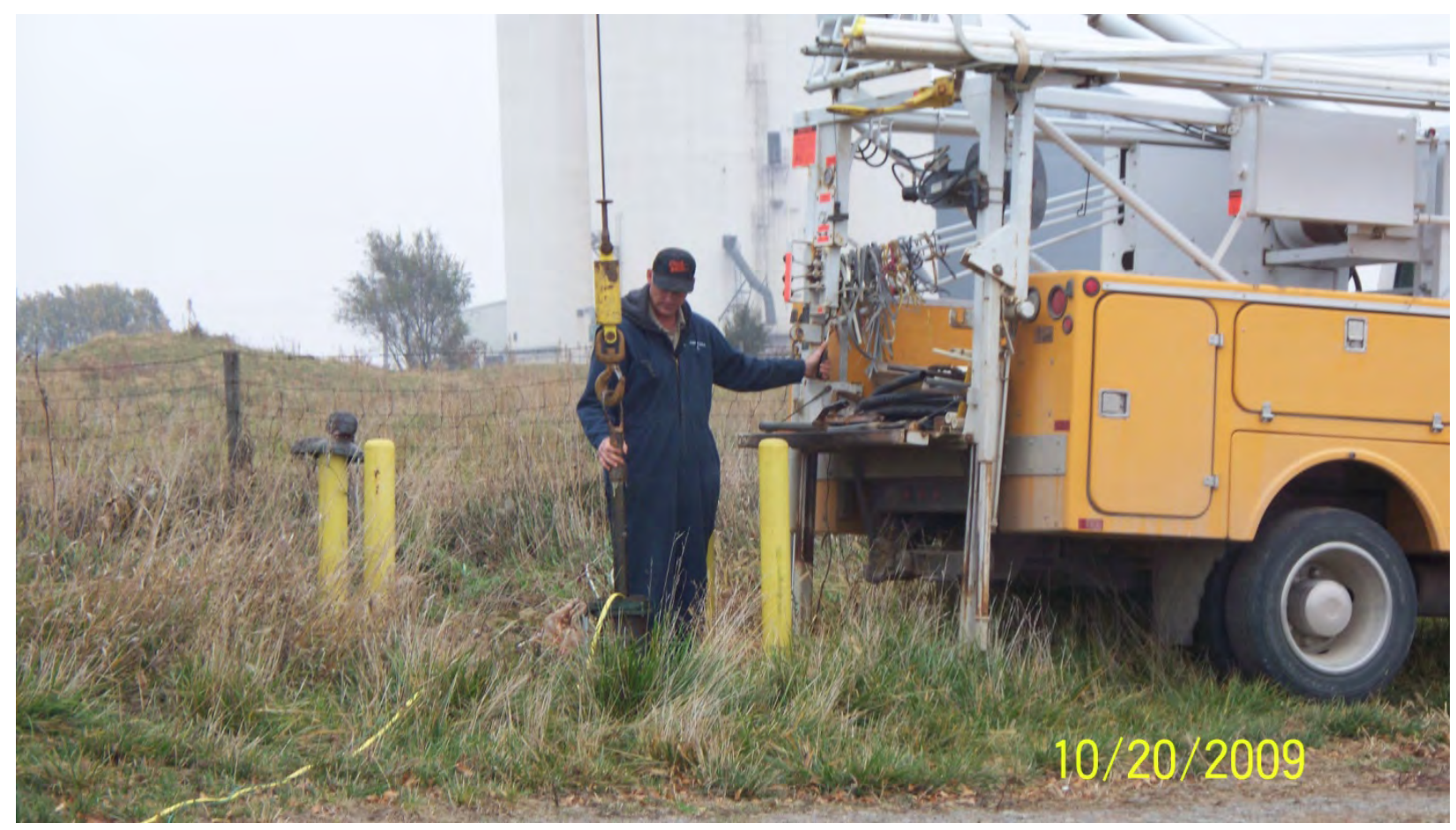

FIGURE 3.1a Servicing of extraction well GWEX4, October 2009, by personnel of Webster Drilling, Inc.

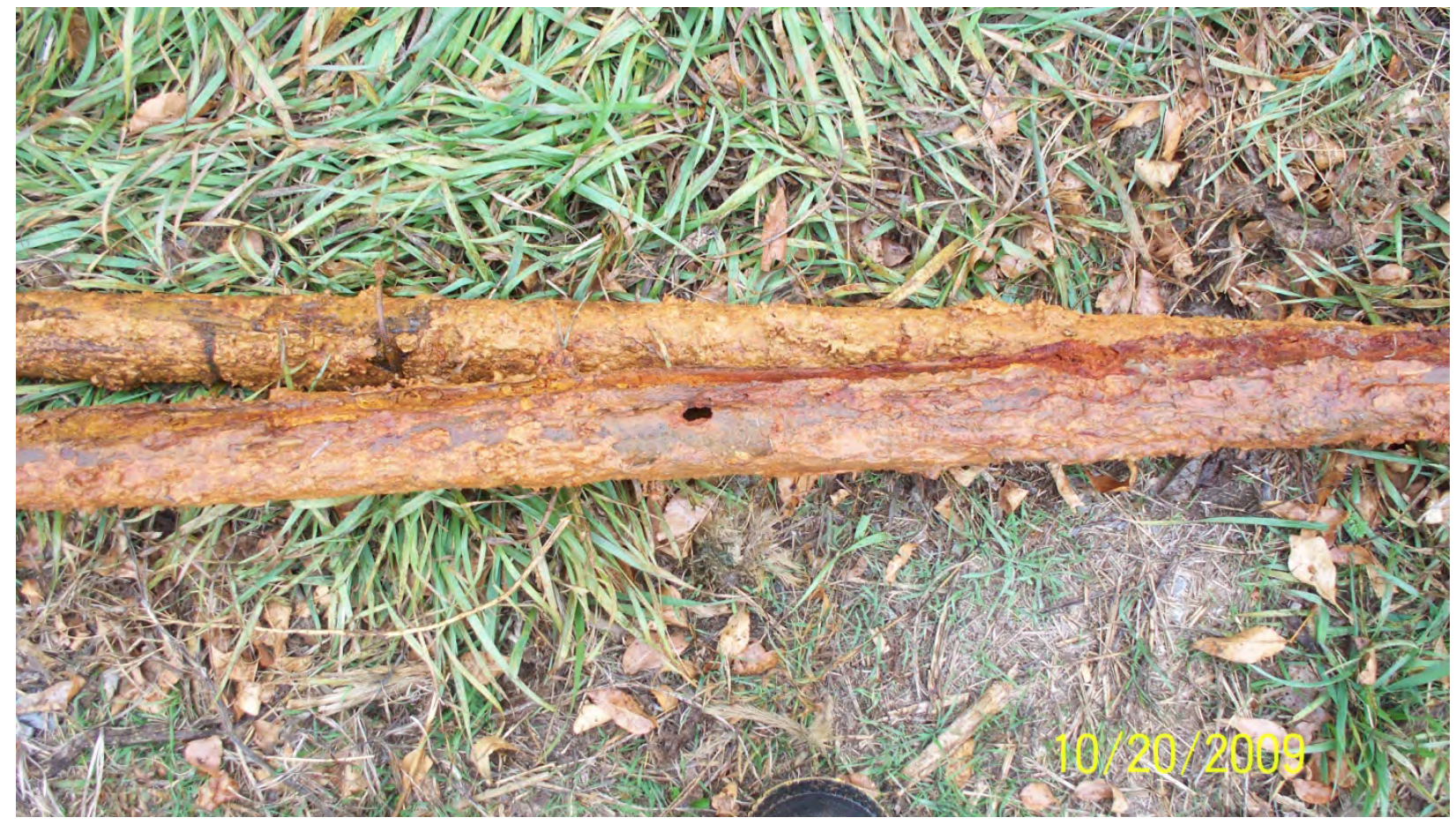

FIGURE 3.1b Corrosion and perforation identified in the steel riser pipe of well GWEX4, October 2009. 


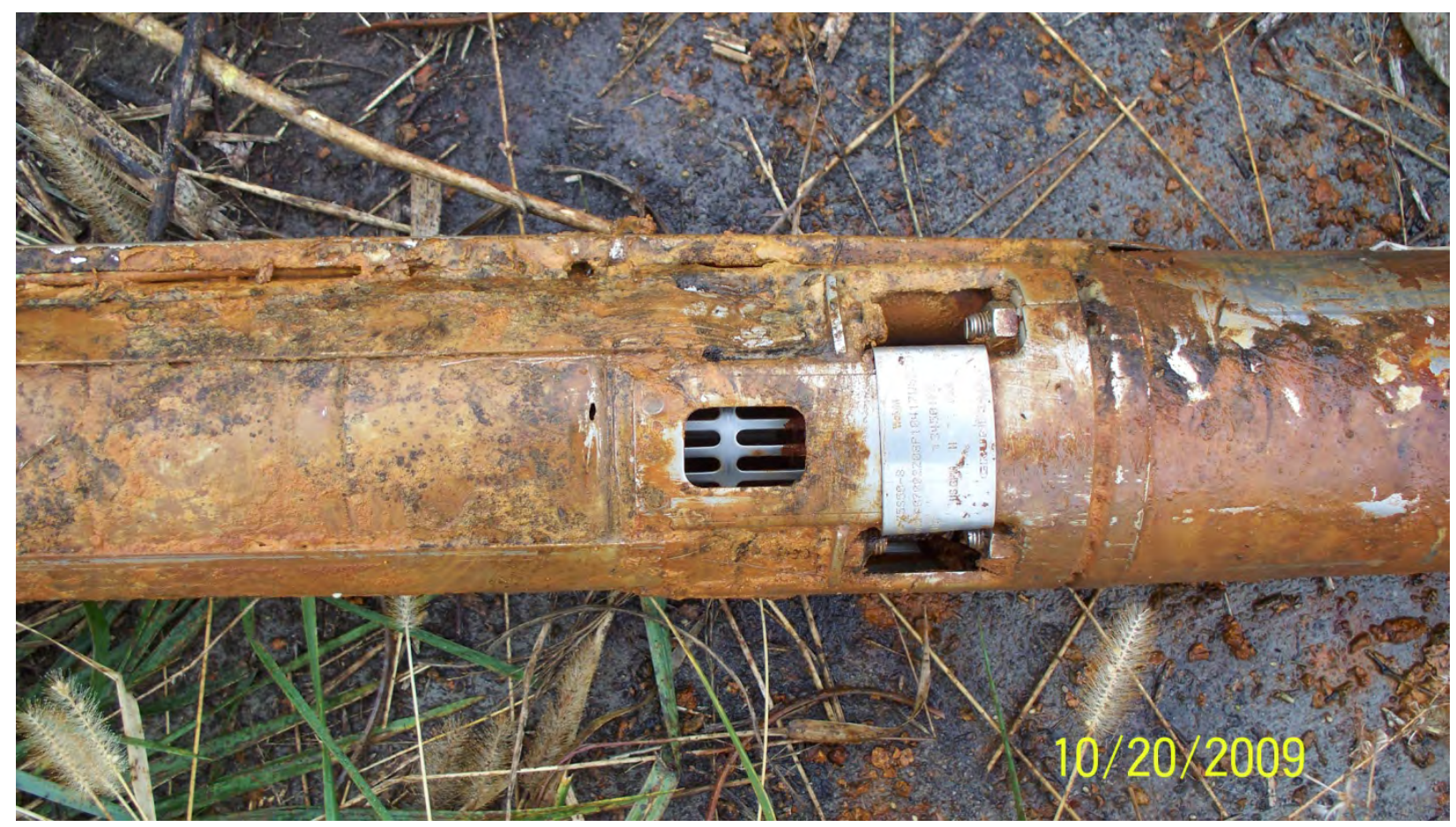

FIGURE 3.1c Corrosion and perforation identified in the downhole pump casing of well GWEX4, October 2009. 


\section{Groundwater Production Results}

The volumes of groundwater extracted from the Utica aquifer, treated, and discharged during the current review period are summarized in Table 4.1. Performance during the $5 \mathrm{yr}$ of system operation to date is summarized in Section 7.

\subsection{Production by Wells GWEX1-GWEX3}

Wells GWEX1-GWEX3 are equipped with electronically controlled pump drive units linked to digital flow meters that automatically and continuously adjust the flow from each well to maintain user-specified pumping rates. During this review period, the programmed flow rates for these wells were as follows:

- GWEX1, 50 gpm

- GWEX2, 200 gpm

- GWEX3, 125 gpm

The selected rates were achieved, within \pm 0.5 gpm, throughout the review period (Table 4.2).

Wells GWEX1-GWEX3 were pumped for approximately 2,250 hr during the review period, and they discharged approximately 50.6 million gallons (156 acre-feet) of treated water to the North Lake Basin wetlands. This represents a significant increase (by approximately 25 million gallons, or 100\%) relative to the previous reporting period, but it is substantially less than the maximum seasonal production total achieved by these wells to date (approximately 91 million gallons), in December 2006-November 2007 (see Section 7). Operation of the spray irrigation treatment systems was prohibited during the winter and spring of the current review period, because unusually high rainfall levels in the summer and fall of 2008 resulted in natural flooding of the wetlands basins and surrounding croplands. The treated groundwater was discharged almost equally to the southern and northern wetlands subbasins, at the request of the NGPC. 


\subsection{Production by Well GWEX4}

Measured groundwater pumping rates (determined from an inline flow meter) at well GWEX4 remained fairly stable, generally ranging from approximately $60 \mathrm{gpm}$ to $65 \mathrm{gpm}$, from December 2008 to early July 2009. As noted in Section 3.2, GWEX4 was shut down from July 9 to August 4, 2009, at the request of the Seward County Department of Roads, to facilitate maintenance of the drainage ditch into which GWEX4 discharges. Declining flow rates from the well observed from early August to early October necessitated another shutdown of GWEX4 for inspection and repair. The well was returned to routine service on October 23, 2009, and then produced at increasing rates, ranging from approximately $60 \mathrm{gpm}$ to $74 \mathrm{gpm}$, through the remainder of the current review period. The volume of groundwater produced in any one complete month of pumping (Table 4.1) ranged from about 2.5 million gallons to 3.1 million gallons. Approximately 26.0 million gallons (80.2 acre-feet) of groundwater was treated and discharged during the review period, at a net average pumping rate (over 365 days) of $49.6 \mathrm{gpm}$. The average flow rate from GWEX4 during the 309 days on which it actually operated during the review period was $58.7 \mathrm{gpm}$. 
TABLE 4.1 GWEX operation and groundwater production data in December 2008-November 2009.

\begin{tabular}{|c|c|c|c|c|c|c|c|c|}
\hline \multirow[b]{3}{*}{ Month } & \multicolumn{4}{|c|}{ Wells GWEX1-GWEX3 (gal) } & \multirow{2}{*}{\multicolumn{2}{|c|}{$\begin{array}{c}\text { Volume Discharged to } \\
\text { Wetlands }^{\mathrm{c}} \text { (gal) }\end{array}$}} & \multicolumn{2}{|c|}{ GWEX4 } \\
\hline & \multicolumn{3}{|c|}{ Groundwater Produced ${ }^{a}$} & \multirow{2}{*}{$\begin{array}{l}\text { Operating } \\
\text { Time }{ }^{\mathrm{b}} \\
\text { (hr) }\end{array}$} & & & \multirow{2}{*}{$\begin{array}{l}\text { Groundwater } \\
\text { Produced } \\
\text { (gal) }\end{array}$} & \multirow{2}{*}{$\begin{array}{l}\text { Operating } \\
\text { Time } \\
\text { (days) }\end{array}$} \\
\hline & GWEX1 & GWEX2 & GWEX3 & & North & South & & \\
\hline Dec 08 & $-{ }^{d}$ & - & - & - & - & - & $2,738,436$ & 31 \\
\hline Jan 09 & - & - & - & - & - & - & $2,814,658$ & 31 \\
\hline Feb 09 & - & - & - & - & - & - & $2,589,938$ & 28 \\
\hline Mar 09 & - & - & - & - & - & - & $2,856,782$ & 31 \\
\hline Apr 09 & - & - & - & - & - & - & $2,766,544$ & 30 \\
\hline May 09 & - & - & - & - & - & - & $2,847,408$ & 31 \\
\hline Jun 09 & $1,131,000$ & $4,519,300$ & $2,830,300$ & 376.9 & $8,480,600$ & - & $2,750,090$ & 30 \\
\hline Jul 09 & $1,764,300$ & $7,072,600$ & $4,426,600$ & 589.5 & $13,263,500$ & - & 750,745 & 10 \\
\hline Aug 09 & 698,500 & $2,783,100$ & $1,734,200$ & 231.8 & $5,215,800$ & - & 932,135 & 28 \\
\hline Sept 09 & $1,320,700$ & $5,273,900$ & $3,313,100$ & 440.3 & - & $9,907,700$ & $1,031,685$ & 22 \\
\hline Oct 09 & $1,070,400$ & $4,306,100$ & $2,687,300$ & 358.4 & - & $8,063,800$ & 851,693 & 7 \\
\hline Nov 09 & 759,100 & $3,040,700$ & $1,902,100$ & 253.4 & - & $5,701,900$ & $3,130,045$ & 30 \\
\hline \multicolumn{9}{|l|}{ Column } \\
\hline Totals & $6,744,000$ & $26,995,700$ & $16,893,600$ & 2,250 & $26,959,900$ & $23,673,400$ & $26,060,159$ & 309 \\
\hline
\end{tabular}

a Combined total production from wells GWEX1-GWEX4: 76,693,459 gal.

b Wells GWEX1-GWEX3 operate simultaneously.

c Total production to wetlands: 50,633,300 gal.

d Unit not in operation.

TABLE 4.2 Comparison of actual well production rates and target rates.

\begin{tabular}{ccc}
\hline & \multicolumn{2}{c}{ Pumping Rate (gpm) } \\
\cline { 2 - 3 } Well & Target & Actual (Net Average) \\
& & \\
\hline & & 50 \\
GWEX1 & 50 & 200 \\
GWEX2 & 200 & 125.1 \\
GWEX3 & 125 & 58.6 \\
GWEX4 & $60-65$ & \\
\hline
\end{tabular}




\section{Groundwater Treatment Results}

Treated groundwater at Utica is discharged under NPDES permit No. NE0137456, issued by the NDEQ on October 1, 2004. The original (5-yr) term of this permit has been indefinitely extended by the NDEQ, pending review of an application for renewal of the permit submitted by the CCC/USDA during the current review period.

To comply with the NPDES requirements, samples of treated groundwater are collected monthly

- At the outlet of the air stripping unit at GWEX4 and

- From the spray discharge at each of the irrigation treatment units (during months of operation).

The samples are analyzed to determine the residual concentrations of carbon tetrachloride in the treated groundwater and the $\mathrm{pH}$ of the effluent. The results of these analyses are reported to the NDEQ quarterly.

The discharges of treated groundwater at Utica are considered by the NDEQ to contribute to the surface waters of the state. On this basis, NDEQ has specified the following compliance limits for the outfall from each treatment unit:

- A target maximum residual carbon tetrachloride concentration of $44.2 \mu \mathrm{g} / \mathrm{L}$

- An acceptable $\mathrm{pH}$ range of 6.5 to 9.0

In conjunction with the compliance sampling, Argonne collects monthly samples of the untreated groundwater from each extraction well. The samples are analyzed for volatile organic compounds (VOCs) to enable estimation of the following:

- Carbon tetrachloride removal efficiencies for the treatment units

- Quantities of carbon tetrachloride removed from the contaminated aquifer 
The results of the sampling and analyses during the review period are summarized in Tables 5.1 and 5.2.

\subsection{Results for Wells GWEX1-GWEX3, with Treatment by Spray Irrigation}

The concentrations of carbon tetrachloride found in the untreated groundwater from extraction wells GWEX2 and GWEX3 were highest upon initial start-up of the wells in June 2009, then generally declined during the relatively continuous pumping in July-November (Table 5.1). Carbon tetrachloride concentrations at GWEX2 ranged from $24 \mu \mathrm{g} / \mathrm{L}$ to $66 \mu \mathrm{g} / \mathrm{L}$, while at GWEX3 the levels ranged from $31 \mu \mathrm{g} / \mathrm{L}$ to $104 \mu \mathrm{g} / \mathrm{L}$.

Observed carbon tetrachloride levels at upgradient extraction well GWEX1 increased from June to August 2009, then showed little further change for the remainder of the current review period. The observed concentrations at GWEX1 showed no apparent correlation to the concentrations observed at GWEX2 and GWEX3. Carbon tetrachloride concentrations at GWEX1 ranged from 26-30 $\mu \mathrm{g} / \mathrm{L}$ in June and July to 54-64 $\mu \mathrm{g} / \mathrm{L}$ in August-November 2009.

The groundwater produced from wells GWEX1-GWEX3 is combined into a single stream for conveyance to the wetlands via a common pipeline. This combined flow is also sampled monthly as an indicator of the weighted average concentration of carbon tetrachloride in the untreated groundwater supplied to the spray irrigation treatment units. The measured concentrations in the combined flow varied from $30 \mu \mathrm{g} / \mathrm{L}$ to $65 \mu \mathrm{g} / \mathrm{L}$ during the current monitoring period. The temporal variations in concentration observed in the combined flow stream generally mirrored those observed at wells GWEX2 and GWEX3, which together contribute approximately $87 \%$ of the total discharge from the extraction well system.

Treated groundwater sprayed from the irrigation units is collected for analysis at the following four locations at the treatment site during each sampling event:

- Beneath the center point of the "west” irrigation span

- Beneath the center point of the “center” irrigation span

- Beneath the center point of the "east” irrigation span 
- At a fourth location visually chosen to reflect the estimated site of maximum spray outfall ("max" value; position varying from month to month; based on prevailing wind and spray conditions at the time of sampling)

The results summarized in Table 5.1 show that the concentrations for all spray samples collected during the review period were below the maximum contaminant level of $5.0 \mu \mathrm{g} / \mathrm{L}$ promulgated by the U.S. Environmental Protection Agency for carbon tetrachloride in drinking water. The maximum carbon tetrachloride level identified for a single sample of spray discharged from the irrigation treatment units was $1.9 \mu \mathrm{g} / \mathrm{L}$. The average concentration of carbon tetrachloride in the treated groundwater discharged to the wetlands was $0.28 \mu \mathrm{g} / \mathrm{L}$. The concentrations of carbon tetrachloride in all spray samples were below the maximum target concentration $(44.2 \mu \mathrm{g} / \mathrm{L})$ allowed under the NPDES permit, by roughly an order of magnitude.

The results of the groundwater and spray sample analyses suggest the following minimum carbon tetrachloride removal efficiency values for the spray irrigation treatment process:

- More than 94\% (based on data for individual samples)

- Approximately 99\% (based on the average concentration delivered to the wetlands during the review period)

The results of $\mathrm{pH}$ measurements recorded for samples of the treated spray discharge are presented in Table 5.2. In all cases, the observed $\mathrm{pH}$ levels (7.48 to 8.43) were within the acceptable range (6.5 to 9.0) specified under the NPDES permit.

\subsection{Results for Well GWEX4, with Treatment by Air Stripping}

Carbon tetrachloride concentrations in the untreated groundwater produced by GWEX4 (Table 5.1) were quite stable (14 $\mu \mathrm{g} / \mathrm{L}$ to $16 \mu \mathrm{g} / \mathrm{L})$ from December 2008 through June 2009. Relatively stable but lower carbon tetrachloride levels (ranging from $6.1 \mu \mathrm{g} / \mathrm{L}$ to $8.8 \mu \mathrm{g} / \mathrm{L}$ ) were recorded at GWEX4 from August to November 2009, following the temporary shutdown of the well in July-early August 2009. Carbon tetrachloride was not detected in the effluent from the air stripping unit throughout the review period, indicating a carbon tetrachloride removal efficiency 
of $>99 \%$ for this process. Measured $\mathrm{pH}$ levels in all samples of the air stripper effluent (6.73 to 8.45; Table 5.2) were within the acceptable range (6.5 to 9.0) specified under the NPDES permit.

\subsection{Estimated Removal of Carbon Tetrachloride from the Utica Aquifer}

The groundwater production and carbon tetrachloride concentration data presented in Tables 4.1 and 5.1, respectively, can be used to estimate the total quantity of carbon tetrachloride extracted by wells GWEX1-GWEX4 from December 1, 2008, to November 30, 2009. The results of these calculations, summarized in Table 5.3, indicate that approximately $9.3 \mathrm{~kg}$ (1.5 gal) of carbon tetrachloride was removed from the Utica aquifer during the present review period. In the previous period (December 2007-November 2008), approximately $8 \mathrm{~kg}$ (1.3 gal) of carbon tetrachloride was removed. These values are significantly lower than the quantities of carbon tetrachloride recovered annually from the Utica aquifer (23-34 kg/yr) during the first $3 \mathrm{yr}$ of operation of the Utica remedial systems, in November 2004-November 2007.

The reduced quantities of carbon tetrachloride removed from the Utica aquifer in the current review period and in December 2007-November 2008 in part reflect decreasing trends in the concentrations of carbon tetrachloride observed in the groundwater produced by wells GWEX2-GWEX4 (see Section 5.4), but they are primarily a consequence of the limited operation of GWEX1-GWEX3 and the spray treatment units that has been possible during these review periods (Section 3.1). No decrease in the volumetric throughput (when operating) or contaminant removal efficiency of the groundwater treatment systems was observed during the current period.

\subsection{Sampling of Monitoring Wells and Apparent Carbon Tetrachloride Concentration Trends in the Utica Groundwater}

Table 5.4 summarizes construction data for the monitoring wells, as well as the results of groundwater sampling and analyses for VOCs during the current review period. Complete monitoring data for wells MW1-MW4, since sampling at these points began in September 2005, are depicted in Figure 5.1. Figures 5.2-5.5 summarize the carbon tetrachloride concentrations measured at GWEX1-GWEX4, respectively, since the routine operation and sampling of these wells began in November 2004. 
Except for MW1, carbon tetrachloride concentrations at all of the monitoring wells (Figure 5.1) have been relatively stable, with no persistent rising or falling trends. Carbon tetrachloride concentrations at MW1 have been consistently greater than those at downgradient monitoring wells MW2-MW4 (Figures 2.1 and 5.1). Concentrations at MW1 increased to a maximum in June-October 2007 (Figure 5.1). The carbon tetrachloride levels at MW1 decreased significantly from October 2007 to December 2008 but then remained relatively stable (100-131 $\mu \mathrm{g} / \mathrm{L})$ during the current review period.

The identified carbon tetrachloride concentrations at downgradient extraction wells GWEX2-GWEX4 (Figures 5.3-5.5) have shown a slow decline during the period of record, although short-term variability is apparent within the generally decreasing trend for each well. In contrast, carbon tetrachloride concentrations at upgradient well GWEX1 (Figures 2.1 and 5.2) have been highly variable and show no clear trend.

Wells MW1 and GWEX1 are located, respectively, on and near the former CCC/USDA facility property (Figure 2.1). Together, the data for MW1 and GWEX1 (Figures 5.1 and 5.2) might reflect a transient, localized influx of carbon tetrachloride to the upgradient shallow groundwater, from residual contamination in the soils beneath the former CCC/USDA facility (Argonne 2000, 2003). The stable or decreasing contaminant levels observed at all of the downgradient monitoring wells and GWEX wells demonstrates, however, that GWEX1 is presently operating effectively as an upgradient capture well.

\subsection{Evaluation of Groundwater Inorganic Geochemistry}

In accord with the approved Monitoring Plan for Utica (Argonne 2004), samples of the untreated groundwater from individual extraction wells GWEX1-GWEX4 and the (treated) effluent from the air stripper at GWEX4 were collected in November 2009 and submitted for inorganic geochemical analyses. No sample was collected for inorganic analyses from the combined flows of GWEX1-GWEX3 during the current review period. The results of the analyses are in Table 5.5, together with equivalent data obtained for these sampling locations in December 2006-November 2007 and December 2007-November 2008. The November 2009 results indicate no substantial changes in the geochemistry of the groundwater produced by the extraction wells, treated, and discharged to the surface near Utica and to the North Lake Basin wetlands during the current review period. 
TABLE 5.1 Analytical results for carbon tetrachloride in untreated groundwater samples and treated effluent samples in December 2008November 2009.

\begin{tabular}{|c|c|c|c|c|c|c|c|c|c|c|c|c|c|c|}
\hline \multirow[b]{3}{*}{ Month } & \multicolumn{14}{|c|}{ Carbon Tetrachloride Concentration ( $\mu \mathrm{g} / \mathrm{L})$} \\
\hline & \multicolumn{4}{|c|}{ GWEX1-GWEX3 Untreated } & \multicolumn{4}{|c|}{ North Spray Unit Effluent } & \multicolumn{4}{|c|}{ South Spray Unit Effluent } & \multirow{2}{*}{$\begin{array}{c}\text { GWEX4 } \\
\text { Untreated }\end{array}$} & \multirow{2}{*}{$\begin{array}{l}\text { Strippe } \\
\text { Effluen }\end{array}$} \\
\hline & GWEX1 & GWEX2 & GWEX3 & Mixed ${ }^{\mathrm{a}}$ & West $^{b}$ & Center ${ }^{b}$ & East $^{\mathrm{b}}$ & $\operatorname{Max}{ }^{C}$ & West $^{\mathrm{b}}$ & Center ${ }^{b}$ & East $^{\mathrm{b}}$ & $\operatorname{Max}$ & & \\
\hline Dec 08 & $-d$ & - & - & - & - & - & - & - & - & - & - & - & 15 & $N D^{e}$ \\
\hline Jan 09 & - & - & - & - & - & - & - & - & - & - & - & - & 16 & ND \\
\hline Feb 09 & - & - & - & - & - & - & - & - & - & - & - & - & 14 & ND \\
\hline Mar 09 & - & - & - & - & - & - & - & - & - & - & - & - & 14.5 & ND \\
\hline Apr 09 & - & - & - & - & - & - & - & - & - & - & - & - & 15 & ND \\
\hline May 09 & - & - & - & - & - & - & - & - & - & - & - & - & 15 & ND \\
\hline Jun 09 & 26 & $64-66^{f}$ & 104 & 65 & ND & ND & ND & ND & - & - & - & - & 14 & ND \\
\hline Jul 09 & 30 & 24 & 58 & 30 & ND & 1.0 & ND & ND & - & - & - & - & 11 & ND \\
\hline Aug 09 & 58 & 38 & 48 & 35 & $0.7 \mathrm{~J}$ & 1.9 & $0.5 \mathrm{~J}$ & 1.0 & - & - & - & - & 7.9 & ND \\
\hline Sep 09 & 64 & 41 & 43 & 46 & - & - & - & - & ND & ND & $0.5 \mathrm{~J}$ & ND & 8.8 & ND \\
\hline Oct 09 & $60-62$ & 30 & $36-43$ & 36 & - & - & - & - & ND & $0.7 \mathrm{~J}$ & ND & ND & 6.1 & ND \\
\hline
\end{tabular}

a Analytical results for samples from the combined flows of GWEX1-GWEX3.

b Samples of spray collected below the center point of the respective irrigation span.

c Samples of spray collected at the estimated location of maximum spray outfall.

d Unit not in operation

e ND, not detected at a method detection limit of $0.1 \mu \mathrm{g} / \mathrm{L}$.

f Ranges of values represent both primary samples and quality control replicates and duplicates.

g Qualifier J indicates an estimated concentration below the quantitation limit of $1.0 \mu \mathrm{g} / \mathrm{L}$ for the purge-and-trap method. 
TABLE 5.2 Values for $\mathrm{pH}$ in untreated groundwater samples and treated effluent samples in December 2008-November 2009.

\begin{tabular}{|c|c|c|c|c|c|c|c|c|}
\hline \multirow[b]{3}{*}{ Month } & \multicolumn{8}{|c|}{$\mathrm{pH}$} \\
\hline & \multicolumn{4}{|c|}{ GWEX1-GWEX3 Untreated } & \multirow{2}{*}{$\begin{array}{l}\text { North } \\
\text { Spray } \\
\text { Unit }{ }^{b}\end{array}$} & \multirow{2}{*}{$\begin{array}{l}\text { South } \\
\text { Spray } \\
\text { Unit }{ }^{b}\end{array}$} & \multirow{2}{*}{$\begin{array}{l}\text { GWEX4 } \\
\text { Untreated }\end{array}$} & \multirow{2}{*}{$\begin{array}{l}\text { Stripper } \\
\text { Effluent }\end{array}$} \\
\hline & GWEX1 & GWEX2 & GWEX3 & Mixed $^{a}$ & & & & \\
\hline Dec 08 & $-^{\mathrm{c}}$ & - & - & - & - & - & $6.14-6.3$ & $7.04-7.22$ \\
\hline Jan 09 & - & - & - & - & - & - & $6.32-6.41$ & $6.73-7.27$ \\
\hline Feb 09 & - & - & - & - & - & - & $6.69-6.76$ & $8.00-8.07$ \\
\hline Mar 09 & - & - & - & - & - & - & $6.28-6.36$ & $7.79-7.81$ \\
\hline Apr 09 & - & - & - & - & - & - & $6.83-6.85$ & $7.90-8.10$ \\
\hline May 09 & - & - & - & - & - & - & $7.36-7.43$ & $7.87-8.15$ \\
\hline Jun 09 & $6.86-6.96$ & $6.7-6.7$ & $6.61-6.63$ & $6.67-6.68$ & $7.85-7.96$ & - & $6.32-6.39$ & $7.65-7.80$ \\
\hline Jul 09 & 7.32-7.39 & 7.11-7.16 & $7.02-7.03$ & $7.36-7.57$ & $7.85-8.37$ & - & $6.18-6.32$ & $7.26-7.87$ \\
\hline Aug 09 & 7.20 & $7.05-7.08$ & $6.97-6.98$ & 7.03-7.04 & $8.21-8.27$ & - & 7.14-7.22 & $8.24-8.36$ \\
\hline Sep 09 & 7.18 & $7.05-7.10$ & 7.01-7.02 & 7.13-7.17 & - & $8.30-8.43$ & $7.23-7.60$ & $8.30-8.45$ \\
\hline Oct 09 & 7.08-7.14 & $6.92-6.98$ & $6.83-6.91$ & $6.94-6.95$ & - & $8.23-8.26$ & $7.05-7.35$ & 8.24-8.45 \\
\hline Nov 09 & 6.67 & $6.59-6.60$ & $6.51-6.52$ & $6.58-6.65$ & - & 7.48-7.71 & $6.53-6.54$ & 8.04 \\
\hline
\end{tabular}

a Ranges of values for multiple measurements of the combined flows of GWEX1-GWEX3.

b Ranges of values for spray samples collected at multiple locations at the discharge site.

c Unit not in operation. 
TABLE 5.3 Estimation of carbon tetrachloride removed from the Utica aquifer in December 2008-November 2009. ${ }^{\text {a }}$

\begin{tabular}{|c|c|c|c|c|c|c|c|c|}
\hline \multirow[b]{4}{*}{ Month } & \multicolumn{4}{|c|}{ GWEX1-GWEX3 } & \multicolumn{4}{|c|}{ GWEX4 } \\
\hline & \multirow{2}{*}{\multicolumn{2}{|c|}{ Groundwater Extracted }} & \multicolumn{2}{|c|}{ Carbon Tetrachloride } & & & \multicolumn{2}{|c|}{ Carbon Tetrachloride } \\
\hline & & & & $\begin{array}{l}\text { Calculated } \\
\text { Amount }\end{array}$ & \multicolumn{2}{|c|}{$\begin{array}{c}\text { Groundwater } \\
\text { Extracted }\end{array}$} & \multirow{2}{*}{$\begin{array}{l}\text { Concentration } \\
\qquad(\mu \mathrm{g} / \mathrm{L})\end{array}$} & \multirow{2}{*}{$\begin{array}{l}\text { Calculated } \\
\text { Amount } \\
\text { Removed } \\
(\mathrm{kg})\end{array}$} \\
\hline & (gal) & $(\mathrm{L})$ & $(\mu \mathrm{g} / \mathrm{L})$ & $(\mathrm{kg})$ & (gal) & $(\mathrm{L})$ & & \\
\hline Dec 08 & $-^{\mathrm{c}}$ & - & - & - & $2,738,436$ & $10,367,719$ & 15 & 0.2 \\
\hline Jan 09 & - & - & - & - & $2,814,658$ & $10,656,295$ & 16 & 0.2 \\
\hline Feb 09 & - & - & - & - & $2,589,938$ & $9,805,505$ & 14 & 0.1 \\
\hline Mar 09 & - & - & - & - & $2,856,782$ & $10,815,777$ & 14.5 & 0.2 \\
\hline Apr 09 & - & - & - & - & $2,766,544$ & $10,474,136$ & 15 & 0.2 \\
\hline May 09 & - & - & - & - & $2,847,408$ & $10,780,287$ & 15 & 0.2 \\
\hline Jun 09 & $8,480,600$ & $32,107,552$ & 65 & 2.1 & $2,750,090$ & $10,411,841$ & 14 & 0.1 \\
\hline Jul 09 & $13,263,500$ & $50,215,611$ & 30 & 1.5 & 750,745 & $2,842,321$ & 11 & 0.03 \\
\hline Aug 09 & $5,215,800$ & $19,747,019$ & 35 & 0.7 & 932,135 & $3,529,063$ & 7.9 & 0.03 \\
\hline Sep 09 & $9,907,700$ & $37,510,552$ & 46 & 1.7 & $1,031,685$ & $3,905,959$ & 8.8 & 0.03 \\
\hline Oct 09 & $8,063,800$ & $30,529,547$ & 36 & 1.1 & 851,693 & $3,224,510$ & 6.1 & 0.0 \\
\hline Nov 09 & $5,701,900$ & $21,587,393$ & 42 & 0.9 & $3,130,045$ & $11,850,350$ & 7.2 & 0.1 \\
\hline TOTAL & & & & 8.0 & & & & 1.3 \\
\hline
\end{tabular}

a Total carbon tetrachloride removed from the aquifer: $9.3 \mathrm{~kg}$.

b Concentration in untreated samples of the combined flow from wells GWEX1-GWEX3.

c Unit not in operation.

d Average. 
TABLE 5.4 Well construction data and analytical results for carbon tetrachloride in groundwater samples from the permanant monitoring wells.

\begin{tabular}{|c|c|c|c|c|c|c|}
\hline \multirow[b]{3}{*}{ Well } & \multicolumn{2}{|c|}{ Depth (ft BGL) } & \multirow{2}{*}{\multicolumn{4}{|c|}{ Carbon Tetrachloride ( $\mu \mathrm{g} / \mathrm{L})$}} \\
\hline & \multirow[b]{2}{*}{ Total } & \multirow{2}{*}{$\begin{array}{l}\text { Screened } \\
\text { Interval }\end{array}$} & & & & \\
\hline & & & Nov 08 & Mar 09 & Jul 09 & Oct 09 \\
\hline SB48 & 98.5 & $83.5-93.5$ & $N D^{a}$ & ND & ND & ND \\
\hline SB71 & 94.2 & 84-94 & ND & ND & ND & ND \\
\hline SB72 & 122.3 & 82.6-112.6 & 1.5 & 1.6 & 5.8 & 7.8 \\
\hline MW1 & 105 & 85-100 & 100 & 131 & 103 & 103 \\
\hline MW2 & 115 & $90-110$ & 12.0 & 21 & 12.0 & 13 \\
\hline MW3 & 125 & $100-120$ & 55 & 55 & 17 & 36 \\
\hline MW4 & 125 & $100-120$ & $3.7-4.0^{b}$ & 3.5 & 3.0 & 2.7 \\
\hline
\end{tabular}

a ND, not detected at a method detection limit of $0.1 \mu \mathrm{g} / \mathrm{L}$.

b Ranges of values represent both primary samples and quality control replicates and duplicates. 
TABLE 5.5 Comparison of inorganic geochemical results for untreated groundwater samples and treated effluent samples

Concentration (mg/L)

\begin{tabular}{|c|c|c|c|c|c|c|c|c|c|c|c|c|c|c|c|c|c|}
\hline \multicolumn{3}{|c|}{ GWEX1 } & \multicolumn{3}{|c|}{ GWEX2 } & \multicolumn{3}{|c|}{ GWEX3 } & \multicolumn{3}{|c|}{ GWEX1-GWEX3 } & \multicolumn{3}{|c|}{ GWEX4 Untreated } & \multicolumn{3}{|c|}{ GWEX4 Effluent } \\
\hline Oct. 2007 & Nov. 2008 & Nov. 2009 & Oct. 2007 & Nov. 2008 & Nov. 2009 & Oct. 2007 & Nov. 2008 & Nov. 2009 & Oct. 2007 & Nov. 2008 & Nov. 2009 & Oct. 2007 & Nov. 2008 & Nov. 2009 & Oct. 2007 & Nov. 2008 & Nov. 2009 \\
\hline$-^{a}$ & - & - & - & - & - & - & - & - & - & - & - & - & - & - & - & - & - \\
\hline$<0.2^{b}$ & $<0.2$ & $<0.2$ & $<0.2$ & $<0.2$ & $<0.2$ & $<0.2$ & $<0.2$ & $<0.2$ & $<0.2$ & - & - & $<0.2$ & $<0.2$ & $<0.2$ & $<0.2$ & $<0.2$ & $<0.2$ \\
\hline 80.4 & 83.9 & 82 & 88.5 & 95.4 & 92 & 100 & 99.7 & 97 & 90.7 & - & - & 105 & 110 & 110 & 108 & 110 & 110 \\
\hline $11 \mathrm{H}^{\mathrm{c}}$ & $\begin{array}{c}13 \\
<01\end{array}$ & 18 & $20 \mathrm{H}$ & 16 & 19 & $21 \mathrm{H}$ & 28 & 23 & $19 \mathrm{H}$ & - & - & $24 \mathrm{H}$ & 31 & 29 & $27 \mathrm{H}$ & 32 & 29 \\
\hline$<0.1$ & $<0.1$ & $<0.1$ & $<0.1$ & $<0.1$ & $<0.1$ & $<0.1$ & $<0.1$ & $<0.1$ & $<0.1$ & - & - & $<0.1$ & $<0.1$ & $<0.1$ & $<0.1$ & $<0.1$ & $<0.1$ \\
\hline $\begin{array}{l}13.3 \\
<0015\end{array}$ & $\begin{array}{l}13.2 \\
<0015\end{array}$ & $\begin{array}{c}13 \\
<0015\end{array}$ & $\begin{array}{c}15 \\
<015\end{array}$ & $<0015$ & $\begin{array}{c}15 \\
<015\end{array}$ & $\begin{array}{l}16.9 \\
<0015\end{array}$ & $\begin{array}{l}16.1 \\
<0.115\end{array}$ & $\begin{array}{l}16 \\
<015\end{array}$ & $\begin{array}{l}15.3 \\
<00\end{array}$ & - & - & $\begin{array}{l}17.7 \\
<0015\end{array}$ & $\begin{array}{l}17.7 \\
<00\end{array}$ & $\begin{array}{l}18 \\
<015\end{array}$ & $\begin{array}{c}18 \\
<0015\end{array}$ & $\begin{array}{c}17.8 \\
<0015\end{array}$ & $\begin{array}{l}19 \\
<015\end{array}$ \\
\hline$<0.015$ & $<0.015$ & $\begin{array}{l}<0.015 \\
<020 \mathrm{H}\end{array}$ & $<0.015$ & $<0.015$ & $<0.015$ & $\begin{array}{l}<0.015 \\
0250 \mathrm{H}\end{array}$ & $<0.015$ & $\begin{array}{l}<0.015 \\
<020 \mathrm{H}\end{array}$ & $\begin{array}{l}<0.015 \\
0210 H\end{array}$ & - & - & $\begin{array}{l}<0.015 \\
0250 \mathrm{H}\end{array}$ & $<0.015$ & $\begin{array}{l}<0.015 \\
<020 \mathrm{H}\end{array}$ & $<0.015$ & $<0.015$ & $\begin{array}{l}<0.015 \\
<020 \mathrm{H}\end{array}$ \\
\hline $\begin{array}{c}0.180 \mathrm{H} \\
0.298\end{array}$ & $\begin{array}{l}0.40 \\
0.307\end{array}$ & $<0.20 \mathrm{H}$ & $0.250 \mathrm{H}$ & $\begin{array}{l}0.39 \\
0291\end{array}$ & 0.37 & $0.250 \mathrm{H}$ & $\begin{array}{l}0.46 \\
0258\end{array}$ & $<0.20 \mathrm{H}$ & $0.210 \mathrm{H}$ & - & - & $0.250 \mathrm{H}$ & 0.42 & $<0.20 \mathrm{H}$ & $0.250 \mathrm{H}$ & 0.40 & $<0.20 \mathrm{H}$ \\
\hline $\begin{array}{l}0.298 \\
5.19\end{array}$ & $\begin{array}{l}0.307 \\
5.38\end{array}$ & $\begin{array}{l}0.28 \\
5.3\end{array}$ & $\begin{array}{l}0.311 \\
5.87\end{array}$ & $\begin{array}{l}0.291 \\
5.83\end{array}$ & 0.31 & 0.312 & 0.258 & 0.31 & $\begin{array}{l}0.308 \\
507\end{array}$ & - & - & $\begin{array}{l}0.283 \\
620\end{array}$ & 0.294 & 0.34 & 0.292 & 0.295 & 0.3 \\
\hline $\begin{array}{l}5.19 \\
13.1\end{array}$ & $\begin{array}{l}3.00 \\
16.9\end{array}$ & $\begin{array}{l}3.5 \\
16\end{array}$ & $\begin{array}{l}3.01 \\
16.9\end{array}$ & $\begin{array}{l}.03 \\
17.2\end{array}$ & $\begin{array}{l}6.2 \\
17\end{array}$ & $\begin{array}{l}6.36 \\
179\end{array}$ & $\begin{array}{l}6.48 \\
179\end{array}$ & $\begin{array}{l}6.4 \\
17\end{array}$ & $\begin{array}{l}5.97 \\
181\end{array}$ & - & - & $\begin{array}{l}6.29 \\
159\end{array}$ & $\begin{array}{l}6.70 \\
102\end{array}$ & 6.5 & 6.4 & $\begin{array}{l}6.50 \\
10 ?\end{array}$ & 7 \\
\hline $\begin{array}{l}13.1 \\
31.8\end{array}$ & $\begin{array}{l}10.9 \\
34\end{array}$ & $\begin{array}{l}10 \\
31\end{array}$ & $\begin{array}{l}10.9 \\
38.2\end{array}$ & 41.6 & $\begin{array}{l}11 \\
36\end{array}$ & 137 & $\begin{array}{l}11.9 \\
378\end{array}$ & $\begin{array}{l}11 \\
40\end{array}$ & $\begin{array}{l}18.1 \\
391\end{array}$ & - & - & & $\begin{array}{l}18.2 \\
446\end{array}$ & $\begin{array}{l}17 \\
41\end{array}$ & & 18.2 & 18 \\
\hline $21 \mathrm{H}$ & $\begin{array}{l}34 \\
26\end{array}$ & $\begin{array}{l}31 \\
20\end{array}$ & $31 \mathrm{H}$ & $\begin{array}{c}41.0 \\
38\end{array}$ & $\begin{array}{l}50 \\
32\end{array}$ & $40 \mathrm{H}$ & 52 & $\begin{array}{l}40 \\
38\end{array}$ & 33.1 & - & - & $\begin{array}{l}44.4 \\
50 . \mathrm{H}\end{array}$ & $\begin{array}{l}44.6 \\
55\end{array}$ & $\begin{array}{l}41 \\
48\end{array}$ & $\begin{array}{l}45.1 \\
54 .\end{array}$ & $\begin{array}{l}44.8 \\
56\end{array}$ & $\begin{array}{l}47 \\
48\end{array}$ \\
\hline $0.07 \mathrm{~B}^{\mathrm{d}}$ & 0.0395 & 0.025 & $<0.02$ & $<0.02$ & $<0.02$ & $<0.02$ & $<0.02$ & $<0.02$ & $<0.02$ & - & - & $<0.02$ & $<0.02$ & $\begin{array}{r}40 \\
<0.02\end{array}$ & $\begin{array}{l}54 \pi \\
<0.02\end{array}$ & $\begin{array}{l}56 \\
<0.02\end{array}$ & $\begin{array}{rl} & 48 \\
<0 & 0.02\end{array}$ \\
\hline $9.1 \mathrm{H}$ & 18 & $10 \mathrm{H}$ & $12 \mathrm{H}$ & 13 & $11 \mathrm{H}$ & $17 \mathrm{H}$ & 18 & $16 \mathrm{H}$ & $13 \mathrm{H}$ & - & - & $16 \mathrm{H}$ & 20 & $19 \mathrm{H}$ & $17 \mathrm{H}$ & 21 & $19 \mathrm{H}$ \\
\hline- & - & - & - & - & - & - & - & - & - & - & - & - & - & - & - & - & - \\
\hline
\end{tabular}

Nitrate-Nitrite N

a No analysis.

b Analyte not identified at analytical method detection limit indicated.

c Qualifier $\mathrm{H}$ indicates that the holding time before analysis was exceeded.

d Qualifier B indicates that the analyte was detected in an associated blank sample. 
Carbon Tetrachloride Concentrations at Monitoring Wells

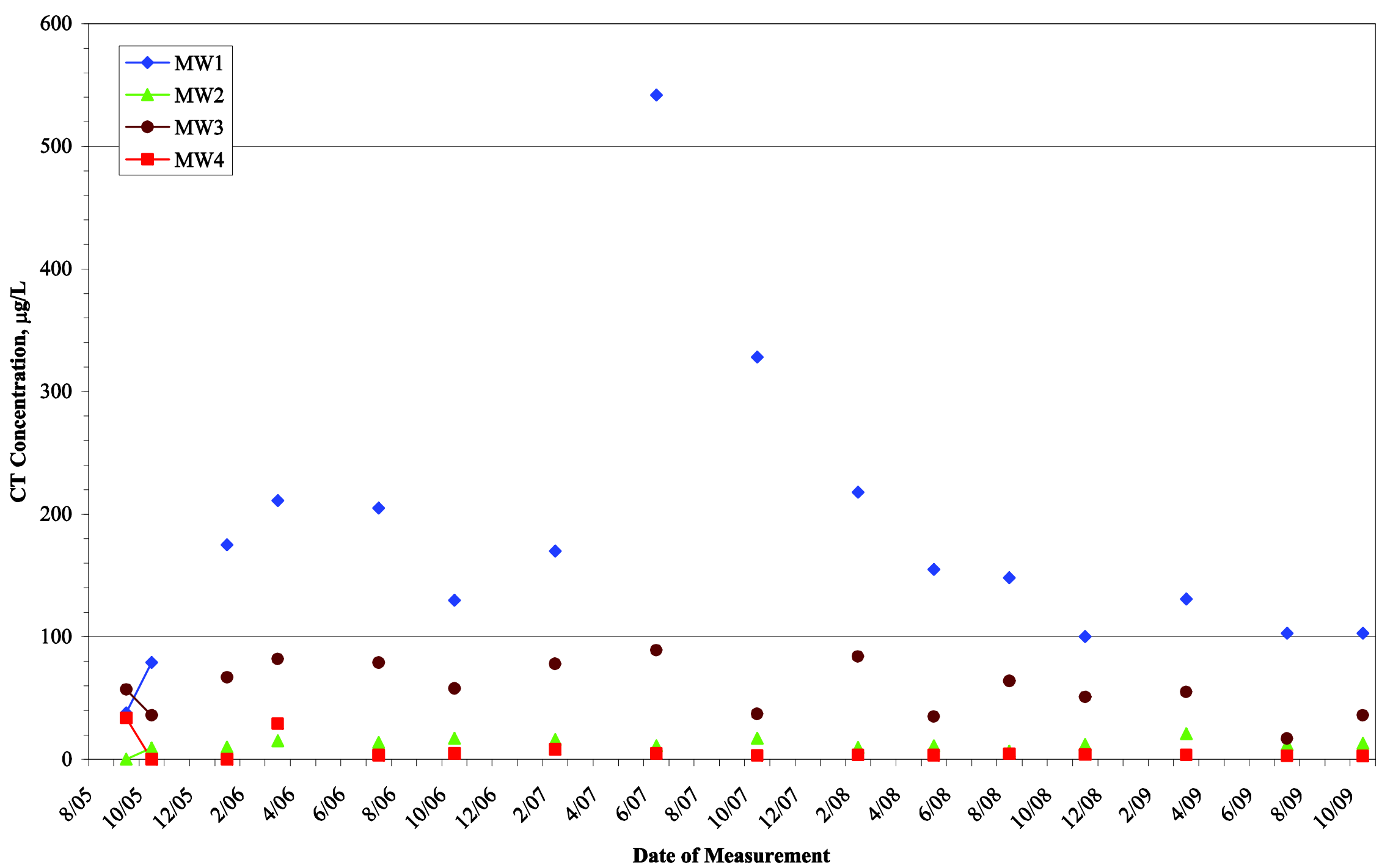

FIGURE 5.1 Carbon tetrachloride concentrations ( $\mu \mathrm{g} / \mathrm{L}$ ) at monitoring wells MW1-MW4, September 2005 to November 2009. 


\section{Carbon Tetrachloride Concentrations at Extraction Well GWEX1}

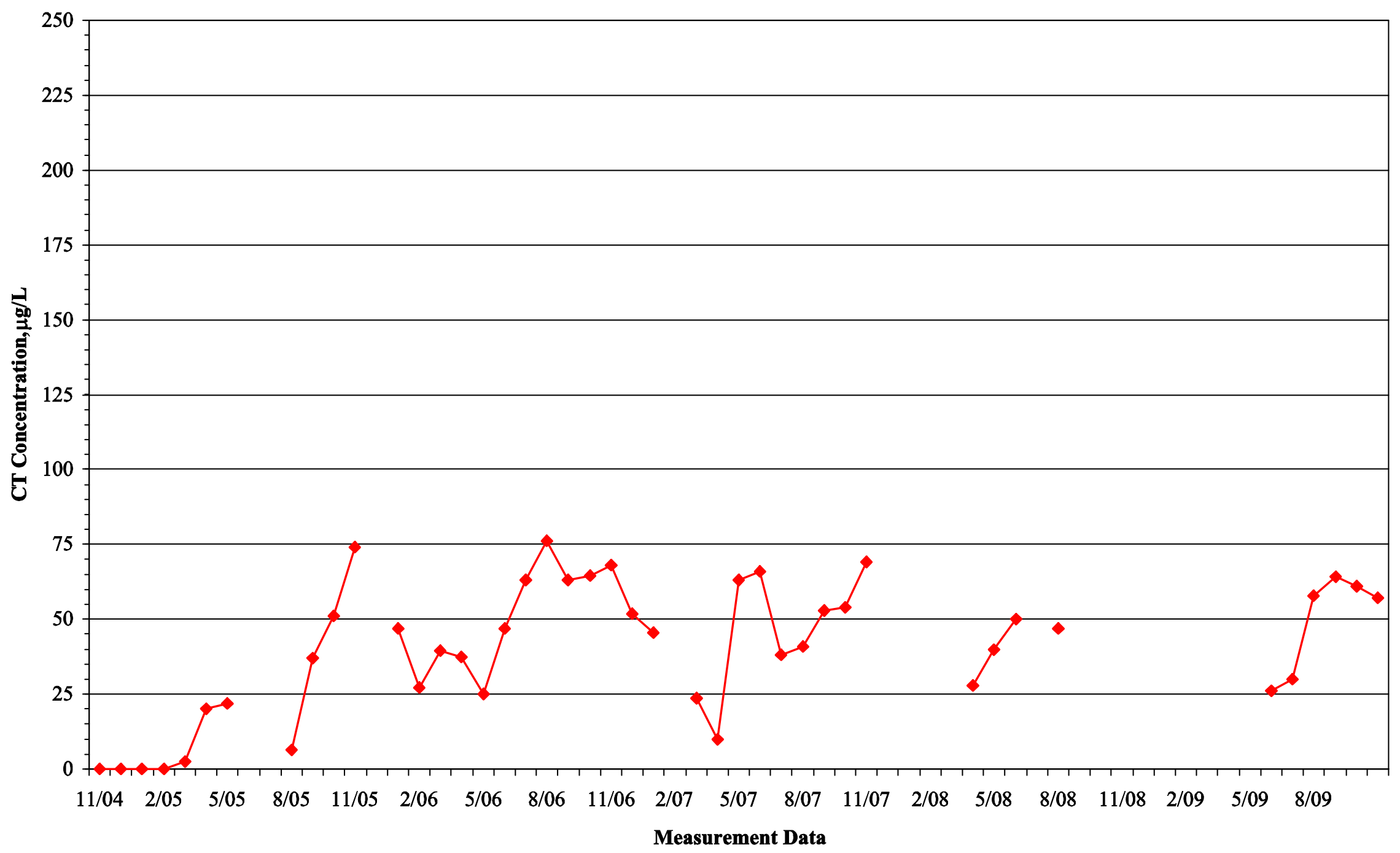

FIGURE 5.2 Carbon tetrachloride concentrations ( $\mu \mathrm{g} / \mathrm{L})$ at extraction well GWEX1, November 2004 to November 2009. 


\section{Carbon Tetrachloride Concentrations at Extraction Well GWEX2}

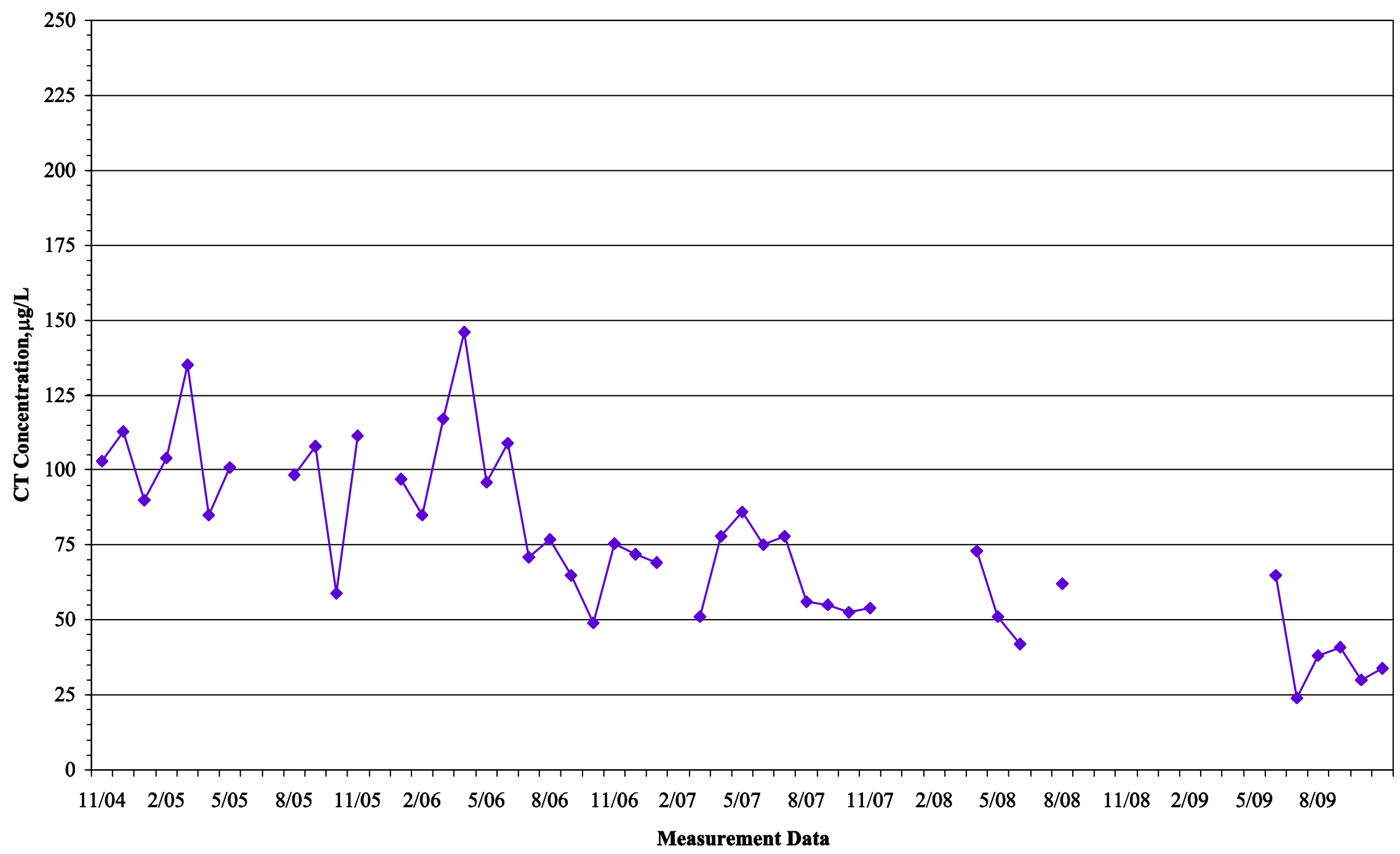

FIGURE 5.3 Carbon tetrachloride concentrations ( $\mu \mathrm{g} / \mathrm{L})$ at extraction well GWEX2, November 2004 to November 2009. 


\section{Carbon Tetrachloride Concentrations at Extraction Well GWEX3}

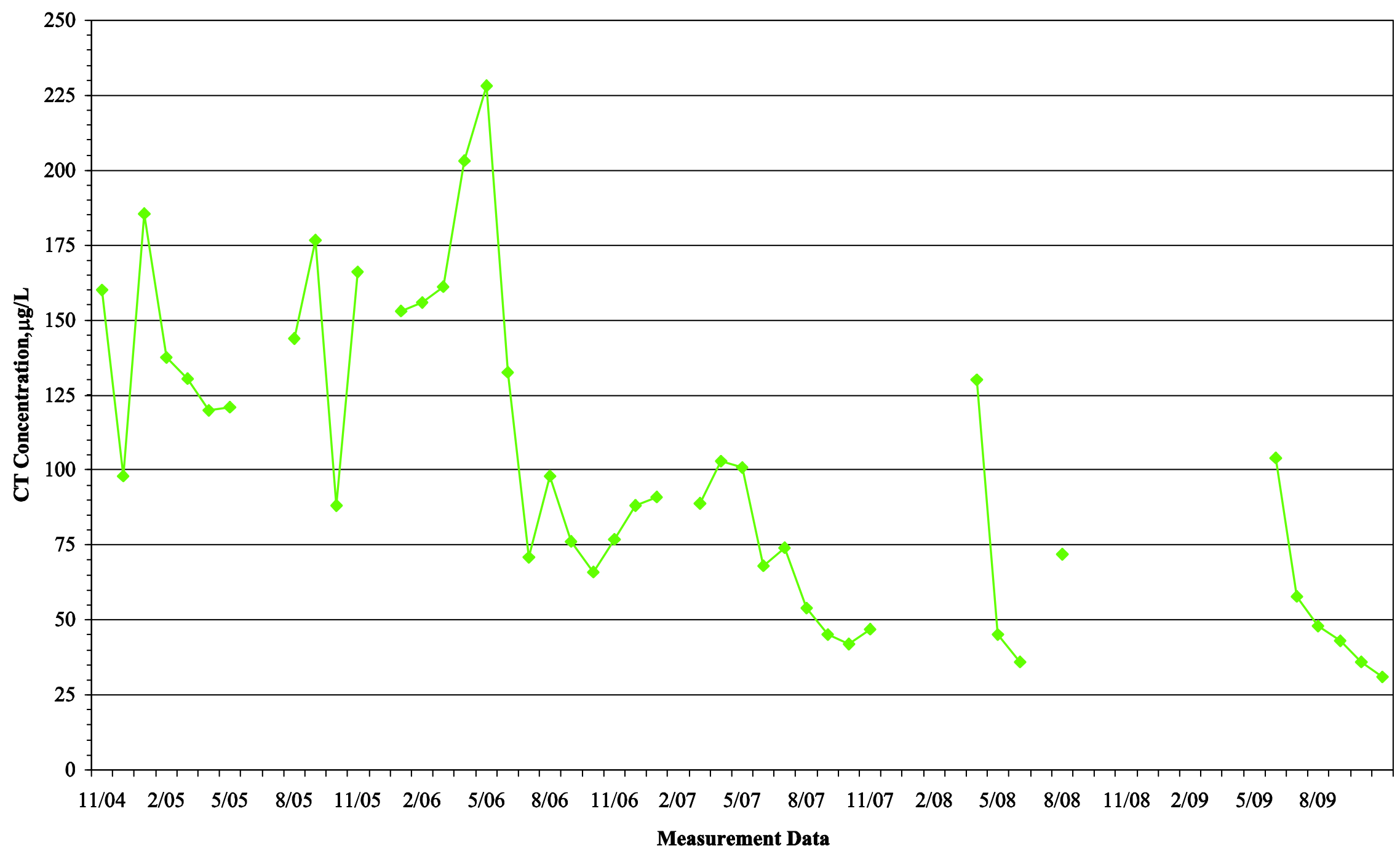

FIGURE 5.4 Carbon tetrachloride concentrations ( $\mu \mathrm{g} / \mathrm{L})$ at extraction well GWEX3, November 2004 to November 2009. 


\section{Carbon Tetrachloride Concentrations at Extraction Well GWEX4}

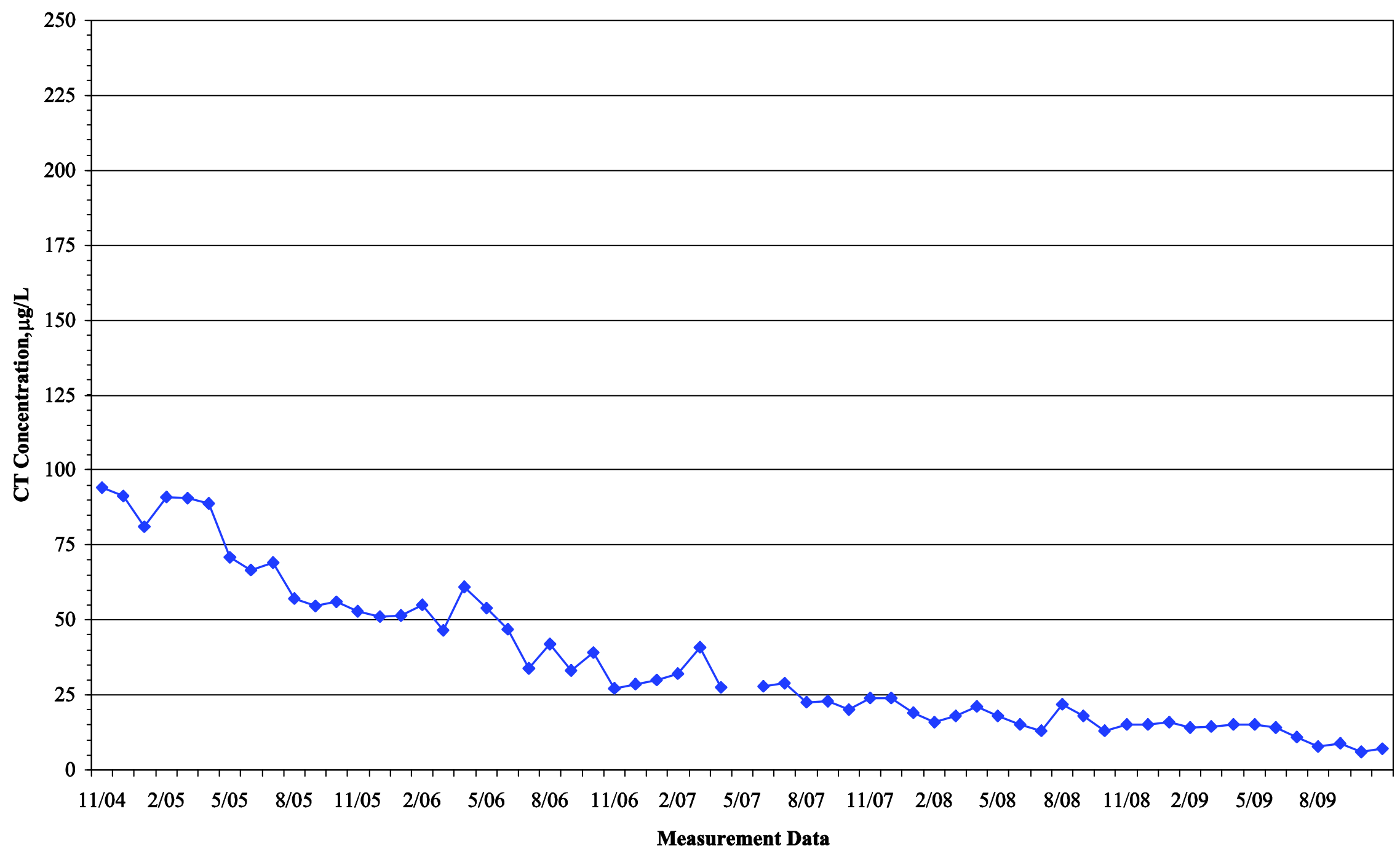

FIGURE 5.5 Carbon tetrachloride concentrations ( $\mu \mathrm{g} / \mathrm{L})$ at extraction well GWEX4, November 2004 to November 2009. 


\section{Operation, Maintenance, and System Modifications}

\subsection{Wells GWEX1-GWEX3 and the Spray Irrigation Treatment Units}

No maintenance was required on extraction wells GWEX1-GWEX3 during the current review period.

Maintenance and repairs for the spray irrigation units and the groundwater delivery system included the following:

- Periodic field inspection of the units and all operating parameters.

- Seasonal mowing along the gravel access roads and pads at the north and south spray treatment sites.

- Redressing and grading of the gravel access roads and pads at the north and south spray treatment sites, to compensate for subsidence that had occurred at several locations since the spray treatment units were installed in 2004.

- Repair of the spray system control panels, purchase of an additional (spare) control panel, and replacement of the pressure sensors (located on one of the irrigation spans at each spray pad, to monitor the spray discharge pressure), as well as connecting wiring at both the north and south spray treatment sites to correct frequent, intermittent system shutdowns and electrical damage caused in part by lightning storms in early August 2009.

Frequent heavy rainfalls during the previous (December 2007-November 2008) review period resulted in high surface water levels throughout the Utica wetlands, plus local flooding of several adjacent private farm properties, that persisted into the winter and spring of 2009. Because of this flooding, operation of GWEX1-GWEX3 and the spray irrigation treatment units was not possible from September 2008 until June 2009. To assist in quantifying the relationship of water levels within the wetlands to the potential for flooding of the surrounding private croplands, the NGPC proposed (during the December 2007-November 2008 review period) a topographic survey of selected critical surface "spill point" locations at the boundaries of the 
NGPC property, as well as the installation of two permanent staff gauges for ready determination of the wetlands water levels (Figure 6.1). With the approval of the CCC/USDA, the recommended topographic survey was performed in March 2009. Large pilings were installed (Figure 6.2) at the two surveyed locations designated as permanent reference points (Figure 6.1) to support graduated staff gauges (Figure 6.3). The gauges were not installed during the current review period, however, because of other critical CCC/USDA field program commitments during the later part of 2009. The gauging stations will be completed during the December 2009November 2010 review period. All preparatory surveys have been accomplished, and the required work will be completed as soon as the winter weather moderates.

\subsection{Well GWEX4 and the Air Stripping Unit}

Maintenance and repairs for well GWEX4 and the air stripping unit included the following:

- Temporary Shutdown. A significant decrease in the output of well GWEX4 was noted in August 2009. The performance of the well continued to decline in August and September. In early October, the well was shut down for inspection and repair. Internal leakage within the well casing was found to be due to corrosion and perforation of the well pump and riser pipe (Figure 3.1b). The pump, the associated electrical wiring, and the riser pipe were replaced.

- Cleaning and Recalibration of Totalizing Flow Meter. In conjunction with the well GWEX4 repairs, the totalizing flow meter employed to monitor the performance of the well was removed and returned to the manufacturer for cleaning and recalibration. An alternate totalizing meter (available from the Argonne inventory of field equipment) was installed as a temporary replacement.

- Visual Inspection and Cleaning. No repairs were required for the air stripping unit at GWEX4 during the current review period. The unit was visually inspected and cleaned in conjunction with the repair of well GWEX4. 


\subsection{Operating and Maintenance Costs}

Operating and maintenance costs for this review period are summarized in Table 6.1. These costs include one-time expenses associated with identification and repair of the corroded riser pipe in well GWEX4, recalibration of the GWEX4 flow meter, and repair of the spray treatment site control panels and spray system pressure gauges.

The total operating and maintenance costs for the Utica project during the current review period $(\$ 160,101)$ decreased by approximately $5 \%$ relative to the equivalent costs for December 2007-November 2008 (\$168,081) and were the second lowest annual costs incurred during the initial $5 \mathrm{yr}$ of operation (Table 6.1). The routine operating costs for the current review period were also the second lowest to date, reflecting a $14 \%$ decrease relative to the previous (December 2007-November 2008) review period. Non-routine costs $(\$ 26,164)$ during the current review period were approximately double those incurred in December 2007-November 2008, primarily because of the repairs required on the spray system control panels and pads and at well GWEX4.

TABLE 6.1 Summary of operating and maintenance costs for the Utica restoration project.

\begin{tabular}{|c|c|c|c|c|c|}
\hline \multirow[b]{2}{*}{ Item } & \multicolumn{5}{|c|}{ Cost $(\$)$} \\
\hline & $\begin{array}{l}\text { Oct 2004- } \\
\text { Nov } 2005\end{array}$ & $\begin{array}{l}\text { Dec 2005- } \\
\text { Nov } 2006\end{array}$ & $\begin{array}{l}\text { Dec 2006- } \\
\text { Nov } 2007\end{array}$ & $\begin{array}{l}\text { Dec 2007- } \\
\text { Nov } 2008\end{array}$ & $\begin{array}{l}\text { Dec 2008- } \\
\text { Nov } 2009\end{array}$ \\
\hline \multicolumn{6}{|l|}{ Routine Costs } \\
\hline General Management & 18,127 & 17,699 & 5,544 & 4,891 & 4,634 \\
\hline Logistics Support & 64,145 & 74,713 & 10,475 & 24,959 & 40,464 \\
\hline Remediation Monitoring & 170,880 & 110,546 & 97,164 & 118,036 & 76,788 \\
\hline Technical Oversight & 17,727 & 5,228 & 13,537 & 8,119 & 12,051 \\
\hline SUBTOTAL & 270,879 & 208,186 & 126,720 & 156,006 & 133,937 \\
\hline \multicolumn{6}{|l|}{ Non-routine Costs } \\
\hline Monitoring Network Establishment & 11,707 & & & & \\
\hline Radio Control System & & 5,140 & & & \\
\hline Irrigation Span Repairs & & 57,591 & & & \\
\hline Valve Actuator Replacement & & & 5,071 & & \\
\hline Repair of Spray Pad Control Panels, & & & & & \\
\hline Replacement of Pressure Sensors & & & 2,265 & & 9,628 \\
\hline Redress Spray Pad Entry Roads & & & & & 2,968 \\
\hline Elevation Survey of Basin Spill-Points & & & & & 6,845 \\
\hline GWEX1 Repairs & & & & 12,075 & \\
\hline GWEX4 Repairs, Flow Meter Recalib. & & & & & 6,723 \\
\hline SUBTOTAL & 11,707 & 62,731 & 7,336 & 12,075 & 26,164 \\
\hline TOTAL & 282,586 & 270,916 & 134,056 & 168,081 & 160,101 \\
\hline
\end{tabular}




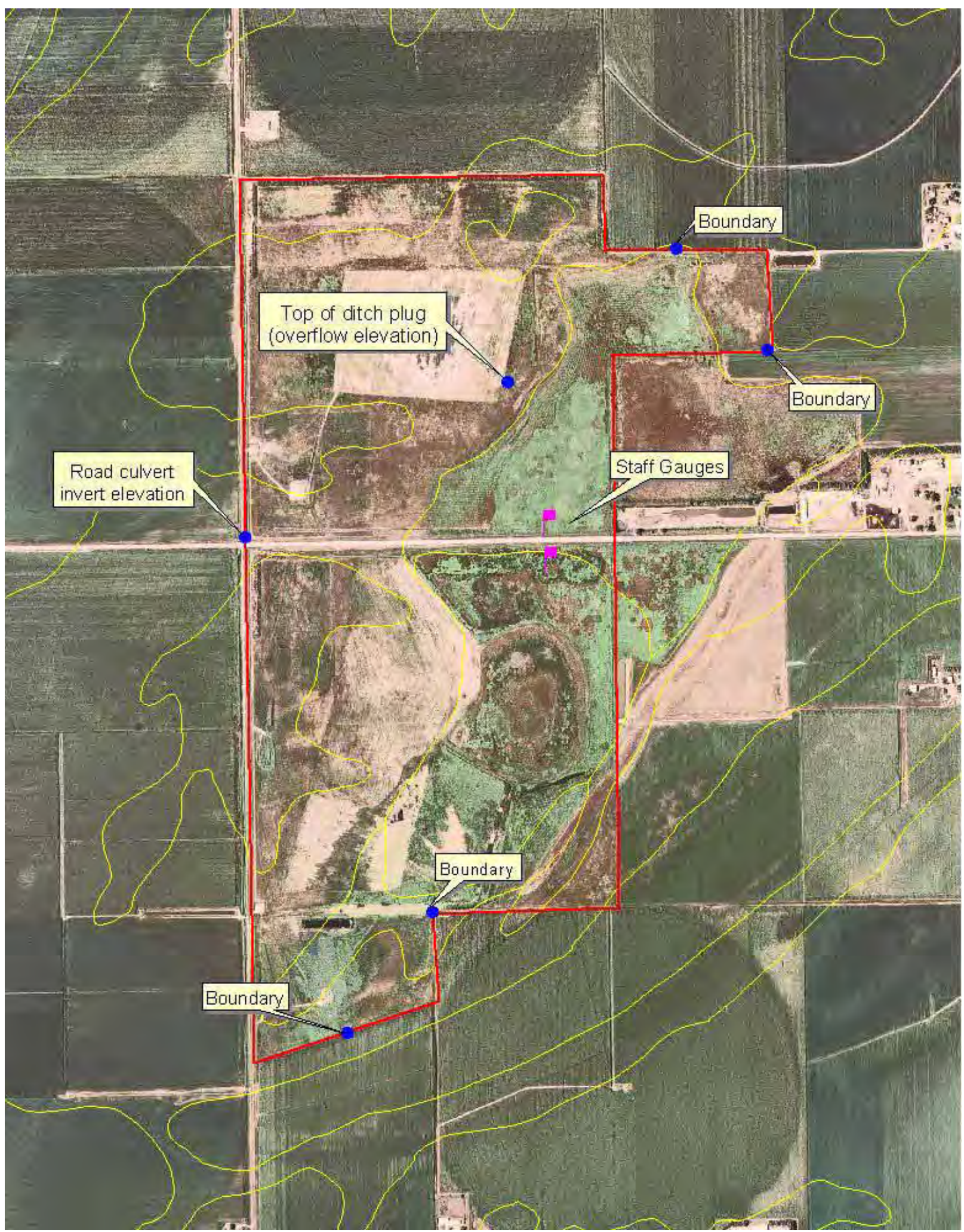

FIGURE 6.1 Locations proposed by the Nebraska Game and Parks Commission for the surveying of topographic elevations and the installation of permanent water level gauging staffs at the North Lake Basin Wildlife Management Area. Surveying was completed and construction of the staff gauges commenced in March 2009. 


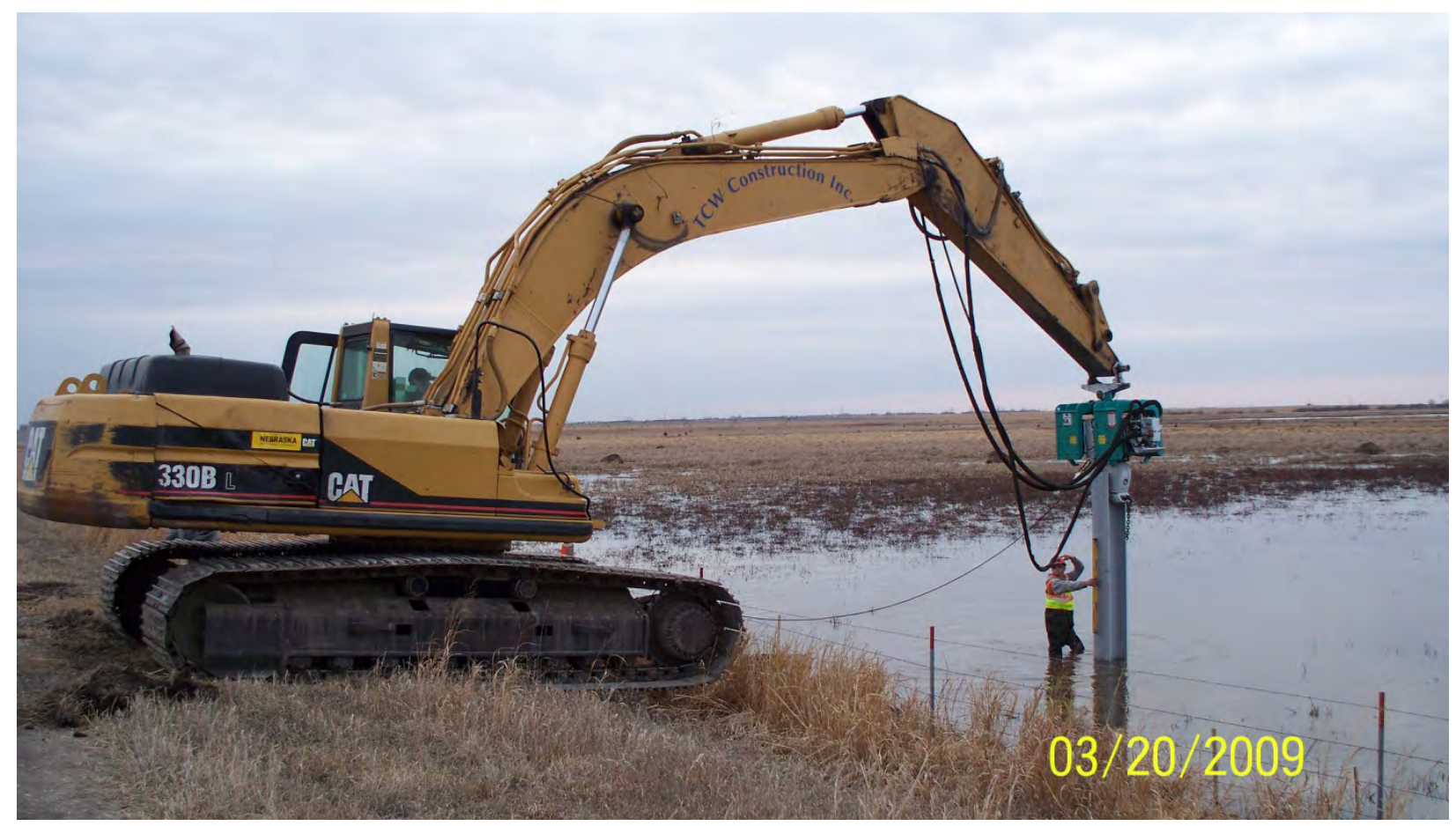

FIGURE 6.2 Installation of H-piling in the north wetlands subbasin to support a permanent water level gauging staff, March 2009. 


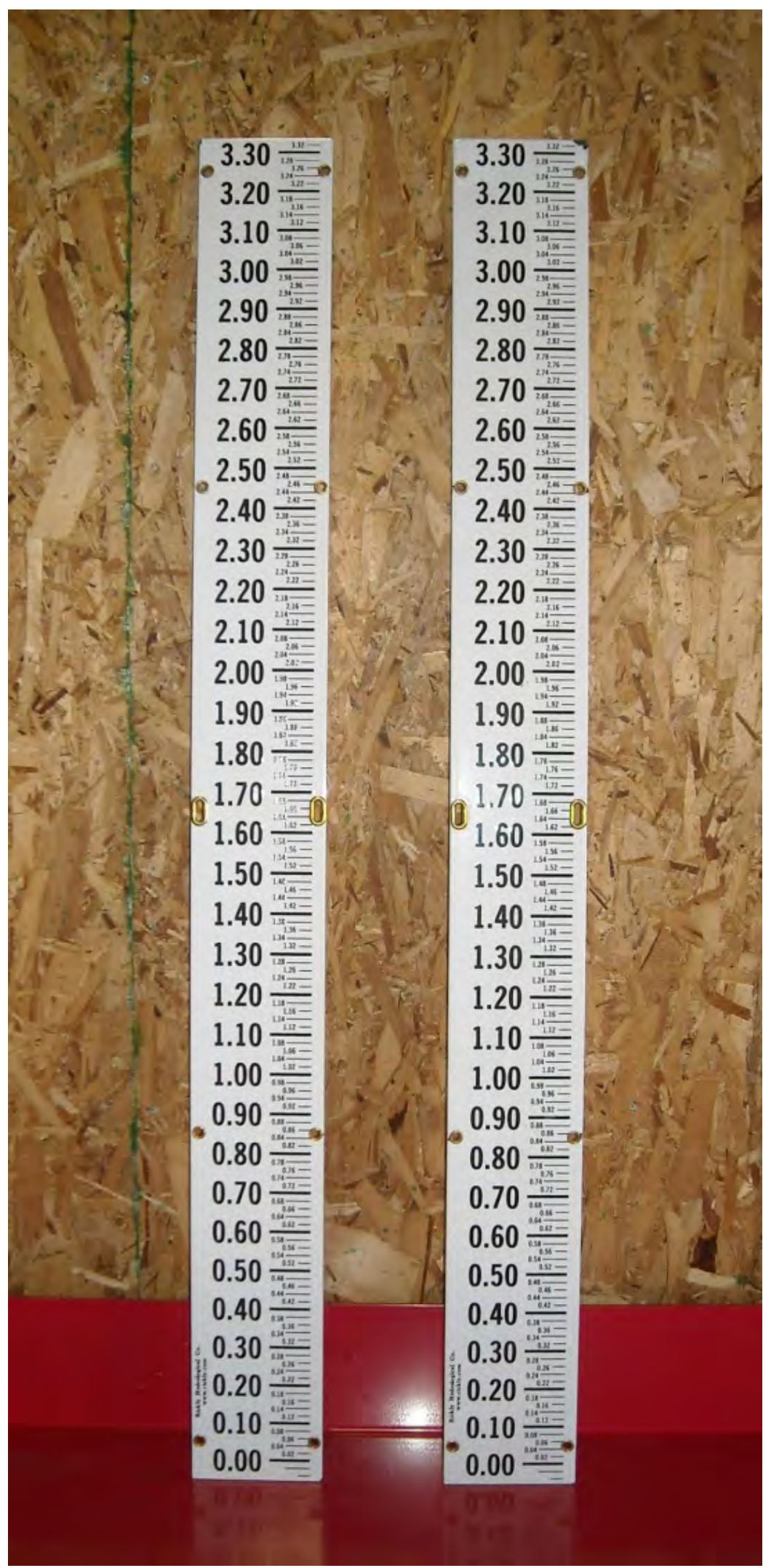

FIGURE 6.3 Graduated water level gauging staffs to be installed in the wetlands subbasins. 


\section{Summary}

Historical performance data and costs for the first $5 \mathrm{yr}$ of operation of the Utica remedial systems are summarized in Tables 7.1 and 7.2.

A combined total of approximately 77 million gallons of contaminated groundwater was extracted and treated during the operation of the aquifer restoration systems at Utica from December 1, 2008, to November 30, 2009. Approximately $66 \%$ of the total volume treated (50.6 million gallons; 156 acre-feet) was used to supplement the natural water entering the North Lake Basin Wildlife Management Area. Discharge of treated groundwater to the wetlands was not possible during approximately half of the current review period (December 2008-May 2009), because of inclement weather conditions and persistent natural flooding of the wetlands basins and the surrounding private croplands.

Groundwater modeling studies performed by Argonne during the development of the aquifer restoration approach for Utica (Argonne 2000) indicated that, on average, the extraction of approximately 97 million gallons of groundwater per year would be required to maintain hydraulic control of the groundwater plume and achieve cleanup of the aquifer in an estimated 10-15 yr. The actual groundwater produced during the December 2008-November 2009 review period represents approximately 79\% of this average annual goal. The highest annual production to date (approximately 119 million gallons; 123\% of the annual target) was achieved in the December 2006-November 2007 monitoring period. The cumulative volume of groundwater extracted and treated by the Utica systems since the aquifer restoration efforts began (Table 7.2) now represents $89 \%$ of the theoretical cumulative target for the 5-yr period November 2004November 2009 (down only slightly from 91\% for the 4-yr period of November 2004-November 2008).

The original modeling studies (Argonne 2000) suggested that the natural rates of groundwater flow and contaminant migration at this site are sufficiently low to accommodate periodic fluctuations in the volume of groundwater extracted annually, as long as the target average extraction rate is generally maintained. The low groundwater recoveries observed during the current (December 2008-November 2009) and previous (December 2007-November 2008) review periods therefore do not represent an immediate concern. The observed trends in carbon tetrachloride concentrations documented at extraction well GWEX4 (Section 5.4; Figure 5.5) indicate that the combined GWEX1-GWEX4 extraction well system is continuing to restrict 
downgradient migration of contamination within the Utica aquifer. If environmental conditions at the wetlands basins continue to significantly affect the groundwater pumping and treatment efforts over numerous consecutive years, however, alternatives might need to be examined to ensure that adequate hydraulic control and recovery of the carbon tetrachloride plume is maintained.

As outlined in Section 3.2 of the approved Monitoring Plan for Utica (Argonne 2004), groundwater sampling with the Argonne cone penetrometer at selected location, as performed at the site by Argonne in 1998 and again in 2003 (Argonne 2003), is recommended at 5-yr intervals to obtain a more detailed picture of the progress of the restoration effort toward completion. Remediation of the Utica aquifer began in fall 2004; recommendations for the first 5-yr performance sampling event have therefore been presented to the CCC/USDA (Argonne 2009b). Implementation of the proposed sampling program is targeted for early in the 2009-2010 review period.

Sampling and analysis of the effluent water from the air stripping and spray irrigation treatment units indicated that during the December 2008-November 2009 review period these systems functioned at a minimum efficiency of $94 \%$ (on the basis of data for individual samples from the spray treatment units). Calculated efficiencies were (1) approximately $99 \%$ for the spray treatment units on the basis of the average concentration delivered to the wetlands during the review period and (2) >99\% for the outfall from the air stripping unit. Carbon tetrachloride concentrations in all discharges of treated water at the site were below the permitted maximum target $(44.2 \mu \mathrm{g} / \mathrm{L})$ by roughly an order of magnitude.

Calculations based on the volumes and measured carbon tetrachloride concentrations of the groundwater extracted and treated during the review period indicated that approximately $9.3 \mathrm{~kg}$ ( $1.5 \mathrm{gal}$ ) of carbon tetrachloride was removed from the Utica aquifer during the December 2008-November 2009 review period. No decrease in the volumetric throughput (when operating) or contaminant removal efficiency of the groundwater treatment systems was observed during the current period (Table 7.1). Table 7.2 shows that approximately $79 \mathrm{~kg}$ (12.75 gal) of carbon tetrachloride has been removed from the Utica aquifer during the first $5 \mathrm{yr}$ (November 2004 to November 2009) of operation of the Utica treatment systems.

The costs incurred by Argonne for operating and maintenance of the aquifer restoration effort at Utica during the December 2008-November 2009 review period were approximately 
$\$ 160,101$, reflecting a decrease of approximately $5 \%$ in total costs and a decrease of approximately $14 \%$ in routine costs relative to the previous (December 2007-November 2008) review period. The current costs include one-time expenses associated with repair of the spray irrigation pads and control panels, the repair of GWEX4, and surveying of selected locations and the installation of permanent surface water level monitoring points at the North Lake Basin wetlands. 
Review Period

\begin{tabular}{|c|c|c|c|c|c|}
\hline & \\
\hline & $\begin{array}{l}\text { Oct 2004- } \\
\text { Nov } 2005\end{array}$ & $\begin{array}{l}\text { Dec 2005- } \\
\text { Nov } 2006\end{array}$ & $\begin{array}{l}\text { Dec } 2006- \\
\text { Nov } 2007\end{array}$ & $\begin{array}{l}\text { Dec } 2007- \\
\text { Nov } 2008\end{array}$ & $\begin{array}{l}\text { Dec } 2008- \\
\text { Nov } 2009\end{array}$ \\
\hline Groundwater Produced (gal) & $66,364,652$ & $113,949,510$ & $119,274,680$ & $55,228,674$ & $76,693,459$ \\
\hline Groundwater Produced (\% of annual goal) & 68 & 117 & 123 & 57 & 79 \\
\hline Groundwater Dlscharged to Wetlands (gal) & $34,611,960$ & $84,365,500$ & $90,954,300$ & $25,675,200$ & $50,633,300$ \\
\hline Carbon Tetrachloride in Combined Untreated Groundwater from GWEX1-GWEX3 ( $\mu \mathrm{g} / \mathrm{L})$ & $100-122$ & $71-139$ & $48-90$ & 43-89 & $30-65$ \\
\hline Carbon Tetrachloride in Treated Spray Discharge ${ }^{\mathrm{a}}$ (range of values, $\mu \mathrm{g} / \mathrm{L}$ ) & $N D^{b}-7.2$ & ND-6.9 & ND-3.7 & ND-4.0 & ND-1.9 \\
\hline Carbon Tetrachloride in Treated Spray Discharge $^{a}$ (average, $\mu \mathrm{g} / \mathrm{L}$ ) & 1.45 & 0.91 & 0.61 & 1.13 & 0.28 \\
\hline Carbon Tetrachloride in Untreated Groundwater at GWEX4 $(\mu \mathrm{g} / \mathrm{L})$ & $53-95$ & $26-70$ & $20-43$ & $13-24$ & 6.1-16 \\
\hline Carbon Tetrachloride in Treated Air Stripper Effluent ${ }^{\mathrm{a}}(\mu \mathrm{g} / \mathrm{L})$ & ND & ND & ND & ND & ND \\
\hline Carbon Tetrachloride Removed (kg, gal) & $23,3.8$ & $34,5.6$ & $25,4.1$ & $8,1.3$ & $9.3,1.5$ \\
\hline \multicolumn{6}{|l|}{ Minimum Carbon Tetrachloride Removal Efficiency for Spray Treatment (\%) } \\
\hline Based on Individual Samples & $>94$ & $>93$ & $>95$ & $>92$ & $>94$ \\
\hline Based on Averages & $\sim 99$ & $\sim 99$ & $\sim 98$ & $\sim 98$ & $\sim 99$ \\
\hline Carbon Tetrachloride Removal Efficiency for Air Stripper (\%) & $>99$ & $>99$ & $>99$ & $>99$ & $>99$ \\
\hline pH of Treated Spray Discharge ${ }^{c}$ & 7.01-8.18 & 7.10-8.32 & 7.09-8.36 & 7.88-8.51 & $7.48-8.43$ \\
\hline $\mathrm{pH}$ of Treated Air Stripper Effluent ${ }^{\mathrm{c}}$ & 7.01-8.35 & $7.50-8.58$ & $7.79-8.33$ & $7.71-8.41$ & $6.73-8.45$ \\
\hline \multicolumn{6}{|l|}{ Costs (\$) } \\
\hline Routine & 270,879 & 208,186 & 126,720 & 156,006 & 133,937 \\
\hline Non-routine & 11,707 & 62,731 & 7,336 & 12,075 & 26,164 \\
\hline TOTAL & 282,586 & 270,916 & 134,056 & 168,081 & 160,101 \\
\hline
\end{tabular}

a Compliance level, $44.2 \mu \mathrm{g} / \mathrm{L}$.

b ND, not detected at a method detection limit of $0.1 \mu \mathrm{g} / \mathrm{L}$.

c Compliance level, 6.5-9.0. 
TABLE 7.2 Results of the groundwater extraction and treatment efforts at Utica, November 2004 to November 2009.

\begin{tabular}{|c|c|c|c|c|c|}
\hline \multirow[b]{2}{*}{$\begin{array}{c}\text { Period } \\
\text { of } \\
\text { Operation }\end{array}$} & \multicolumn{2}{|c|}{ GWEX1- GWEX3 } & \multicolumn{2}{|c|}{ GWEX4 } & \multirow[b]{2}{*}{$\begin{array}{l}\text { Groundwater } \\
\text { Produced } \\
\text { (\% of } \\
\text { annual goal) }\end{array}$} \\
\hline & $\begin{array}{l}\text { Production } \\
\text { (gal) }\end{array}$ & $\begin{array}{c}\text { Carbon } \\
\text { Tetrachloride } \\
\text { Removed } \\
(\mathrm{kg})\end{array}$ & $\begin{array}{l}\text { Production } \\
\text { (gal) }\end{array}$ & $\begin{array}{c}\text { Carbon } \\
\text { Tetrachloride } \\
\text { Removed } \\
(\mathrm{kg})\end{array}$ & \\
\hline 11/04-11/05 & $34,611,960$ & 14.2 & $31,752,692$ & 9.0 & 68 \\
\hline 12/05-11/06 & $84,365,500$ & 29.2 & $29,584,010$ & 5.0 & 117 \\
\hline $12 / 06-11 / 07$ & $90,954,300$ & 21.8 & $28,320,380$ & 3.0 & 123 \\
\hline $12 / 07-11 / 08$ & $25,675,200$ & 6.0 & $29,553,474$ & 2.0 & 57 \\
\hline 12/08-11/09 & $50,633,300$ & 8.0 & $26,060,159$ & 1.3 & 79 \\
\hline Totals & $286,240,260$ & 79.2 & $145,270,715$ & 20.3 & $89^{a}$ \\
\hline
\end{tabular}

a Average production. 


\section{References}

Argonne, 2000, Final Report: Stage I Investigations of the Agricultural/Environmental Enhancement Pilot Program, Utica, Nebraska, prepared for the Commodity Credit Corporation, U.S. Department of Agriculture, by Argonne National Laboratory, Argonne, Illinois, January.

Argonne, 2003, Update on Groundwater Sampling Results for Utica, Nebraska, and Pumping Alternatives for the Utica Aquifer/Wetlands Restoration Pilot Program, ANL/ER/AGEM/CHRON-484, prepared for the Commodity Credit Corporation, U.S. Department of Agriculture, by Argonne National Laboratory, Argonne, Illinois, April 9.

Argonne, 2004, Final Monitoring Plan for the Utica Aquifer-North Lake Basin Restoration Project at Utica, Nebraska, ANL/ER/TR-04/006, prepared for the Commodity Credit Corporation, U.S. Department of Agriculture, by Argonne National Laboratory, Argonne, Illinois, November.

Argonne, 2005, Summary of First-Year Operations and Performance of the Utica Aquifer and North Lake Basin Wetlands Restoration Project in October 2004-November 2005, ANL/EVS/AGEM/TR-05-06, prepared for the Commodity Credit Corporation, U.S. Department of Agriculture, by Argonne National Laboratory, Argonne, Illinois, December.

Argonne, 2006, Summary of Operations and Performance of the Utica Aquifer and North Lake Basin Wetlands Restoration Project in December 2005-November 2006, ANL/EVS/AGEM/TR06-11, prepared for the Commodity Credit Corporation, U.S. Department of Agriculture, Washington, D.C., by Argonne National Laboratory, Argonne, Illinois, December.

Argonne, 2008, Summary of Operations and Performance of the Utica Aquifer and North Lake Basin Wetlands Restoration Project in December 2006-November 2007, ANL/EVS/AGEM/TR08-05, prepared for the Commodity Credit Corporation, U.S. Department of Agriculture, Washington, D.C., by Argonne National Laboratory, Argonne, Illinois, February.

Argonne, 2009a, Summary of Operations and Performance of the Utica Aquifer and North Lake Basin Wetlands Restoration Project in December 2007-November 2008, ANL/EVS/AGEM/TR09-02, prepared for the Commodity Credit Corporation, U.S. Department of Agriculture, Washington, D.C., by Argonne National Laboratory, Argonne, Illinois, January. 
Argonne, 2009b, Update on the Aquifer/Wetlands Restoration Project at Utica, Nebraska, with Recommendations for Remapping of the Carbon Tetrachloride Contamination in Groundwater, ANL/EVS/AGEM/TR-09-10, prepared for the Commodity Credit Corporation, U.S. Department of Agriculture, by Argonne National Laboratory, Argonne, Illinois, October. 


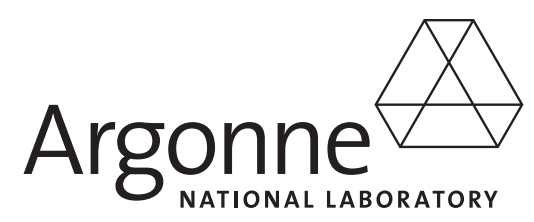

\section{Environmental Science Division}

Argonne National Laboratory

9700 South Cass Avenue, Bldg. 203

Argonne, IL 60439-4843

www.anl.gov 